\title{
EFFECT OF DIETARY ENERGY INTAKE ON NUTRIENT UTILIZATION, PERFORMANCE, AND MAINTENANCE REQUIREMENTS IN LATE GESTATION COWS AND THEIR CALVES
}

\author{
A Thesis \\ by \\ LONISA MARIE EARLY \\ Submitted to the Office of Graduate and Professional Studies of \\ Texas A\&M University \\ in partial fulfillment of the requirements for the degree of \\ MASTER OF SCIENCE
}

\begin{abstract}
Chair of Committee, Tryon A. Wickersham
Co-Chair of Committee, Jason E. Sawyer

Committee Members, Chris L. Skaggs

Elizabeth Parker

Head of Department, $\quad$ G. Cliff Lamb
\end{abstract}

December 2017

Major Subject: Animal Science

Copyright 2017 Lonisa Marie Early 


\begin{abstract}
Sixty multiparous, late-gestation beef cows (462 kg initial BW) were limit-fed, high-concentrate diets. Cows were blocked by BW and individually fed one of four treatments $(70,85,100$, and $115 \%$ of NRC-predicted maintenance energy) in Calan gates for an average of $71 \mathrm{~d}$ prior to calving. Diets consisted of $2.00 \mathrm{~kg}$ of wheat straw $(2.5 \% \mathrm{CP} ; 79 \% \mathrm{NDF})$ and one of four levels of a mixture of corn $(45 \%)$, distiller's grain (42\%) and premix (13\%) fed 2.70, 3.41, 4.12, and $5.84 \mathrm{~kg} / \mathrm{d}$ to correspond with the 70 , 85,100 , and $115 \%$ treatments. Digestible energy intake increased linearly $(5.92,6.78$, 7.77 and $8.86 \mathrm{Mcal} / \mathrm{d}$ for $70,85,100$, and $115 \% ; P<0.01)$ per design. No effects $(P>$ 0.05) for diet digestion were observed; DM digestion averaged 62\%. Cow retained energy during the limit-feeding period (d 0 to 52) increased linearly $(P<0.01)$ from 46.6 Mcal for $70 \%$ to $50.7,106.3$, and $123.8 \mathrm{Mcal}$ for 85,100 , and $115 \%$. Body weight gain increased linearly over the same time period $(P<0.01)$ from $0.7 \mathrm{~kg}$ for $70 \%$ to 3.6 , 17.7 , and $24.2 \mathrm{~kg}$ for 85,100 , and $115 \%$. Calf birth weight increased linearly $(P=0.01)$ from $32.5 \mathrm{~kg}$ for $70 \%$ to $35.5,35.2$, and $36.8 \mathrm{~kg}$ for 85,100 , and $115 \%$. Brix (\%) values for colostrum at parturition and $24 \mathrm{~h}$ post parturition did not differ $(P>0.05)$. Immunoglobulin $\mathrm{G}$ levels in calf serum collected at birth, $24 \mathrm{~h}$ and $7 \mathrm{~d}$ did not differ $(P$ > 0.05) and averaged 0, 4,749, and 4,464 mg/dL, respectively. Cow body weights remained greater (linear, $P<0.05$ ) in cows fed increasing levels of energy at days 60 and 90 post parturition; however, treatments no longer differed $(P>0.05)$ at 120 or 160 days post parturition or at weaning their calves (d 270). Level of energy intake during gestation did not result in significant differences $(P>0.05)$ in calf weights at $60,90,120$
\end{abstract}


or 160 days post parturition or at weaning (averaged $206 \mathrm{~kg}$ ). Cow 30 and $60 \mathrm{~d}$ conception rates were $82 \%$ and $98 \%$, respectively. 


\section{DEDICATION}

I'm silly thrilled to dedicate this thesis, but more importantly the work, scientific intrigue and animal appreciation it represents to my mom - my role model in all of those things, and more.

Mom,

You've given me a lot, like comfort when I needed it, a reality check when I may not have wanted it, a listening ear whenever I asked for it and unconditional love when I didn't deserve it. Thank you.

I've often thought the phrase, "I wouldn't be here if it weren't for you," a bit trite but in this case it fits so well. Sure I wouldn't be alive, okaaay, but I also wouldn't be interested in animal science, in always learning more, okay with being on my own adventure in a strange place (Texas can be strange) and dedicated to mustering the grit to finish. You shared all of those things with me and I wouldn't be here if it weren't for you. Thank you.

You are the hardest working, goat-wranglin, horse-tamin person I know. You are kind to strangers. You are internally competitive. You are a "look it up in the Merck," stickler who cries at happy stories and laughs at sarcasm. You are the greatest friend I've ever had. Thank you.

I'm listening to Patsy Cline, sipping wine and watching Angus Ferguson play with his mouse while I write this, small ways I become more and more like you as I

world. For everything, mom, thank you! 


\section{ACKNOWLEDGEMENTS}

Dr. Wickersham and Dr. Sawyer: I feel that a graph describing my appreciation of you would speak to you the most, so here it is:

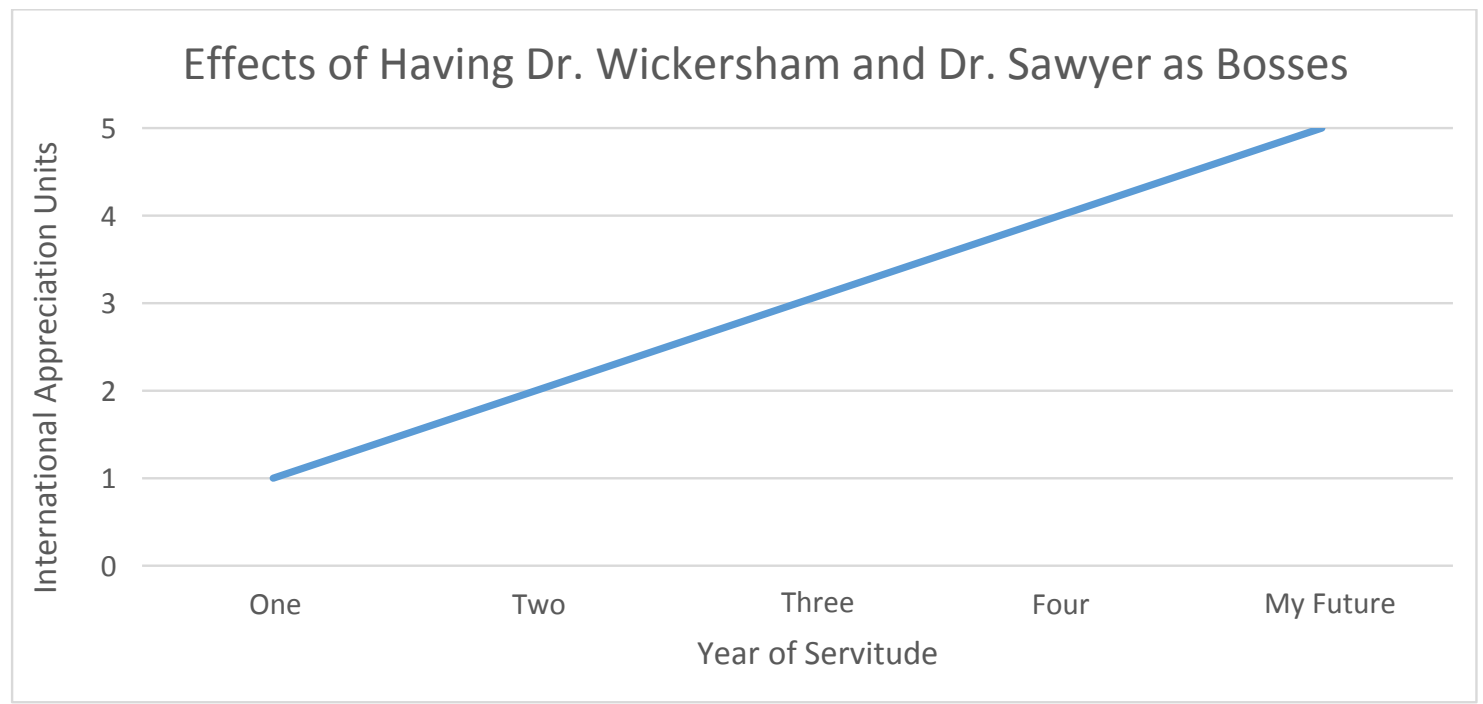

Thank you for celebrating and supporting who I am as a person while simultaneously fostering my consistent growth. Thanks for your sincere, honest and regularly available mentorship. I feel a sense of pride and insanely lucky every time I tell people who I work for. Which is then followed by the desire to clarify, "but actually, they always make it feel more like I work with them." Thank you!

To the SSTC crew: there's no group of humans I'd rather collect, grind, measure and burn poop with than you. They say you become the average of the people you spend the most time with.... I'd make a stats joke about an outlier or standard error of the mean or something here but I (clearly) don't know statistics that well...the point is, your talent and hard work makes me better. Thank you. 
To the 491 students who helped with my cow project: For the sleepless nights on those lovely cots- This is awful, was that a ghost? Why did I sign up? Just some of your thoughts. The next morning came Early- we gotta feed that cow, gotta get that sampleEven though "sleep" was less than ample. Time to feed, time to sweep- Saying this is fun, would definitely be a leap. And now we're covered in hay that really itches- And dang those cows are a bunch of...nice ladies. For reals though, that's one mean cowSurely we'll get that blood, just not sure how. Then it was time to wrangle a calf in the pasture- Thinking man, I wish this mule would go fast-ure. But with joy in your hearts and smart brains in your heads- You worked hard, and ensured the cows and calves weren't the deads. You did it! You made it happen! From feeding, and birthing to sampling and watching cows crap'n. I've seen each of you succeed as an over achieverAnd can honestly say, in you, I'm a believer. From O1 Red to Crazy on the End - Thank you for your help, enthusiasm and to each of you for becoming a friend

Alisa, thank for your patient, thoughtful and non-judgmental responses to, "hey can you look over this? It's due in (blank) hours." Thank you for being such a solid a voice of wisdom, a glamping master and an outlet for endless cat snaps! I look up to you and thank you!

Fred, Elizabeth, K Forks, and the Paulks: thank you for making College Station and my life oodles better throughout my masters. Can you imagine how crazy I would be without you? The world and I thank you. Also, thanks to Fred for loving Angus more than he deserves. Who are we kidding, he deserves it. Cutest little. 
On that note, thanks Angus Ferguson for (it's not ridiculous to thank one's cat, just to clarify) being the best little gato a crazy cat lady could ask for. And for never deleting the only copy of this document when you laid/walked across my keyboard. I would have sold you. Thanks Beyoncé, T-Sweezy and Lin Manuel Miranda for your artistic gifts which became the soundtracks of \#thethesisgrind. To my cows and calves, I appreciate the body of knowledge you brought to the world and richness you brought to my life. Seriously. I love you, even the mean ones, Ol' Red the most though.

Thank you to my friends far and wide, having community is so important and I am endlessly thankful for the one you have created for me regardless of location. Thank you to my family, and the Shinns and Cummings as families that have joined along the way, for supporting me when I was just a weird goat girl. I guess at this point we can't blame it on the goats. Your words of encouragement and love have carried me through the good and bad days and to places I couldn't have imagined were within if not for you!

Words of affirmation clearly isn't my top love language so I'm incredibly thankful for the quality time I've spent with the people (and creatures) I've mentioned and hope I can return the acts of service they've brought to me . 


\section{CONTRIBUTORS AND FUNDING SOURCES}

This work was supervised by a thesis committee consisting of Dr. Tyron

Wickersham, co-chair, Dr. Jason Sawyer, co-chair, of the Department of Animal

Science, Dr. Chris Skaggs of the College of Agriculture and Life Sciences and Dr.

Elizabeth Parker of the Institute for Infectious Diseases.

All work for the thesis was completed by the student, under the advisement of

Drs. Tryon Wickersham and Jason Sawyer of the Department of Animal Science.

Funding Sources Section (no funding)

There are no outside funding contributions to acknowledge related to the research and compilation of this document. 


\section{TABLE OF CONTENTS}

Page

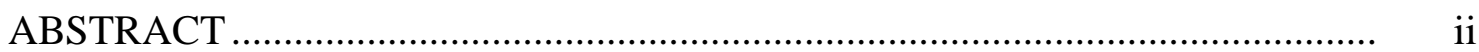

DEDICATION .................................................................................... iv

ACKNOWLEDGEMENTS ....................................................................... v

CONTRIBUTORS AND FUNDING SOURCES .......................................... viii

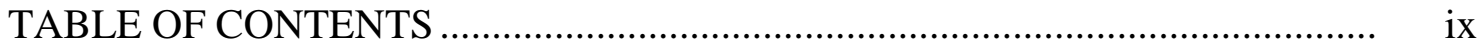

LIST OF TABLES ..............................................................................

CHAPTER I INTRODUCTION AND REVIEW OF LITERATURE................. 1

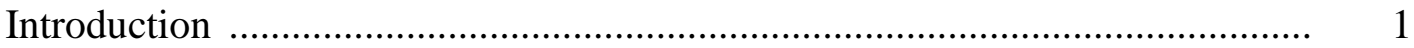

The Beef Industry's Energetic Contributions to Society ................................ 4

Significance of Energy Exchanges in the Beef Industry ............................... 7

Contributions to Energy Expenditure in Beef Cattle ...................................... 11

Changing Energy Expenditure in Beef Cattle: Increasing Efficiency ................ 18

Energy Exchange from Dam to Calf ..................................................... 20

Overall Summary ........................................................................... 25

CHAPTER II EFFECT OF DIETARY ENERGY INTAKE ON NUTRIENT

UTILIZATION, PERFORMANCE, AND MAINTENANCE REQUIREMENTS IN LATE GESTATION COWS AND THEIR CALVES ............................................................ 27

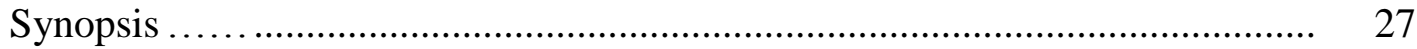

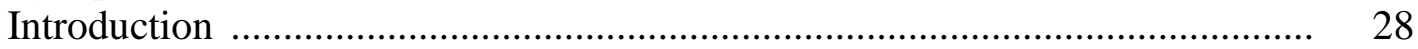

Materials and Methods ......................................................................... $\quad 30$

Laboratory Analysis ...................................................................... 34

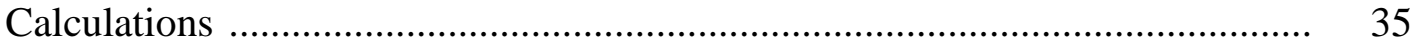

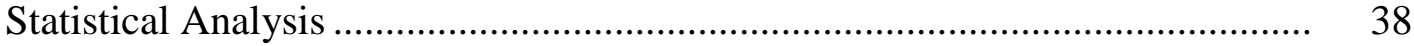

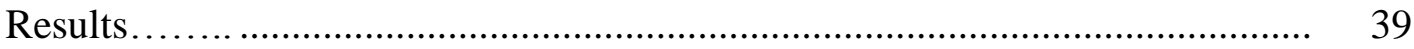

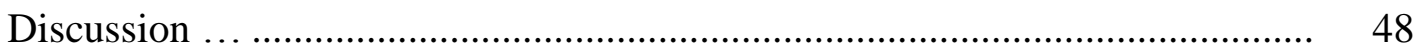

CHAPTER III SUMMARY ….................................................................. 51

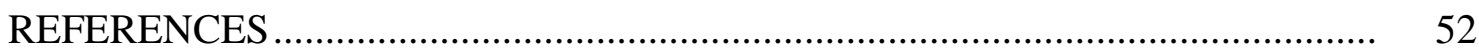




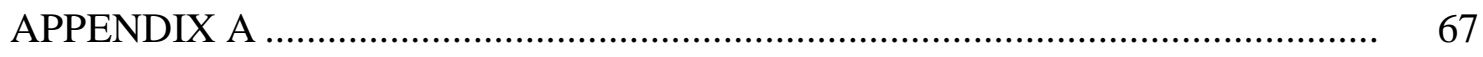




\section{LIST OF TABLES}

TABLE Page

2.1 Formulated Ingredient and Nutrient Composition of Treatment Diets ......

2.2 Apparent Nutrient Digestion of Treatment Diets Fed to Confined Beef Cows at Four Different Levels of NRC Predicted Requirements for Maintenance

2.3 Apparent Energy Availability of Treatment Diets and Estimates of Retained Energy and Heat Production in Confined Beef Cows Fed at Four Different Levels of NRC Predicted Requirements for Maintenance

2.4 As-fed Consumption of Treatment Diets Fed to Confined Beef Cows at Four Different Levels of NRC Predicted Requirements for Maintenance

2.5 Calving and Post Calving Body Weight and Condition Score Measurements of Confined Beef Cows Fed at Four Different Levels of NRC Predicted Requirements for Maintenance.

2.6 Initial and Final Body Weight and Ultrasound Measurements, Over a 52 d Limit-feeding Period, of Confined Beef Cows Fed at Four Different Levels of NRC Predicted Requirements for Maintenance

2.7 Body Weight Measurements of Progeny from Beef Cows Fed in Confinement at Four Different Levels of NRC Predicted Requirements for Maintenance.

2.8 Colostrum Measurements Beef Cows Fed in Confinement at Four Different Levels of NRC Predicted Requirements for Maintenance

2.9 Serum Immunoglobulin G Measurements of Progeny from Beef Cows Fed in Confinement at Four Different Levels of NRC Predicted Requirements for Maintenance

3.1 Cow Metabolite Measures 


\section{CHAPTER I}

\section{INTRODUCTION}

\section{Introduction}

Life requires energy, or the capacity to do work. Hall et al. (2009) argue that societies, systems and organisms that do not amass energetic profits will cease to persist. Even so, determining the best approach to securing surplus energy through the multivariate complexities that accompany a large and growing population is difficult. Additionally, shrinking profit margins, increased production costs, political incentives and social pressures have put a strain on surplus energy acquisition. Though driving factors, courses of implementation and even its definition are widely contested, increased sustainability via increased efficiency in production has been the ubiquitous approach to realizing energetic profits in public and private sectors.

Complex questions, such as how to acquire surplus energy, require complex problem solving approaches, one example is the modern decision support tool. Since their extensive application beginning in the early 1970's, decision support tools, characterized by the use of data and models to inform decision makers of effective problem solving actions, have dramatically changed the environment in which global businesses operate (Eom and Kim, 2006). To better understand that change, Eom et al. (2006) surveyed the tools published between 1995 and 2001. Their scholarly search delimited to, “decision support systems," returned more than 1600 published articles, from which 271 were selected for further analysis based on their adherence to the following criteria: inclusion of descriptions regarding the decision(s) in question, the 
human-computer interface and support utilized, and the data-dialog-model system. Though the selected articles represented decision support tools in phases ranging from initial design to a finished and utilized product, the authors cautioned considering the list to be all inclusive of decision support tools in existence globally, especially considering many remain unpublished. However, trends in decision support tools identified from their findings are justifiably representative; The most significant being that the largest percentage (41\%) of decision support tools they surveyed were utilized to inform production and operation management (POM) decisions, ultimately aimed at optimizing business production, i.e. achieving the highest productivity considering relevant limitations.

Worrell et al. (2003) reveal application of productivity decisions; they describe productivity as the "relationship between the quantity of goods and services produced by a business or an economy and the quantity of labor, capital, energy, and other resources that are needed to produce those goods and services." They describe productivity advancements as those capable of any one or combination of the following: lowering capital and operating costs, increasing yields and reducing energy and resource use. However, they indicate that the zenith of production impacts come from the implementation of 'energy-efficient' technologies because they not only reduce energy use but also increase productivity.

Worrell et al. (2003) examined the connection between energy efficiency and productivity in a review of 77 case studies from the U.S. iron and steel industry. In doing so, they developed a methodology to assess productivity related outcomes connected to 
investments in energy saving technologies. Their methodology of analysis included cost analysis, productivity impacts and energetic savings potential. Their work reported productivity related benefits, i.e. those outside of strictly energy-related benefits, resulting from energy efficient technologies into the following five groups: 1) waste reduction, 2) emission reduction, 3) reduced maintenance and operating costs, 4) increased production and quality of production, and 5) augmented working conditions. In an analysis of the potential impacts of energy saving technologies in the U.S. iron and steel industry, those that included calculation of productivity related benefits showed twice the energy saving potential compared to those that did not include productivity benefits, resulting in a difference close to 170 petajoules in annual energy savings across the industry.

Eom and others (2006) shed light on the number of firms seeking to understand how to improve their productivity with the use of decision support tools and Worrell et al. (2003) defend increasing energy efficiency as the preeminent answer with the greatest number of benefits. Surplus energy acquisition, via increased production efficiency is worthy of substantial and global consideration and application across various industries, and the outcomes of which will undoubtedly affirm its utility. For example, the total global energy required to generate one unit of GDP decreased by 1.3 percent per year between 1990 and 2011. A portion of this decrease can be ascribed to energy efficiency programs across multiple sectors (Enerdata, 2013). In another example, U.S. agrarian outputs, including crops and livestock have increased, on average, 1.49 percent each year between 1948 and 2011. However, use of production inputs including land, labor, 
and fertilizer have increased by only 0.07 percent each year during that same time period (Wang et al., 2015), suggesting evidence of energy management in the agriculture sector.

The beef industry's energetic contributions to society

By converting human inedible energy, i.e. forage and bi/co-products from other industries, to a human-edible protein with a greater biological value (Oltjen and Beckett, 1996), beef production has an intrinsic capacity to realize an energetic profit, or the ability to make 'more from less,' at the societal level. This is significant because the estimated contribution of animal-sourced foods comprises $16 \%$ of the calories and $36 \%$ of the protein consumed by humans across the globe (Delgado et al., 1998). Global per capita supply of beef is $9.41 \mathrm{~kg} / \mathrm{yr}$ which equates to $40 \mathrm{Kcal} / \mathrm{d}$, while the United States' is $37 \mathrm{~kg} / \mathrm{yr}$ and $102 \mathrm{Kcal} / \mathrm{d}$ (FAOSTAT, 2016). To think about this, if the global per capita beef supply of $9.41 \mathrm{~kg} / \mathrm{yr}$ is multiplied by the 2016 global population of 7.4 billion humans (Population Reference Bureau, 2016) we get an estimated 69 billion $\mathrm{kg}$ of beef produced per year. De Vries and De Boer, (2010) determined in a life-cycle assessment of non-organic beef production in the UK that it takes $27,800 \mathrm{MJ} / \mathrm{kg}$ of energy to produce $1 \mathrm{~kg}$ of beef. Multiplying the annual 69 billion $\mathrm{kg}$ of beef by their estimate of 27,800 MJ/kg, yields 1.9 quadrillion $\mathrm{MJ} / \mathrm{yr}$ as the total energy used for global beef production. A two-percent reduction of this total, which is on par with the reduction of the energy used by the U.S.'s beef value chain between 2005 and 2011 (Cattlemen's Beef Board and National Cattlemen's Beef Association, 2014) would equate to 38 
trillion MJ/yr in energetic savings. Global beef production represents a large-scale energy saving potential, justifying inquiry into this space.

In addition to contributing to human caloric needs with a highly-palatable and nutrient-dense food, the beef industry also provides by-products (secondary products made during the manufacturing of another product) that may be used in a different industry, such as: leather and other textiles, organic fertilizer, industrial oils, soaps, additives in cosmetic products etc. In addition to by-product production, the beef industry is capable of utilizing by-products from other industries such as distiller's grains from the ethanol industry. In different operations around the world beef animals are kept for their fringe benefits such as vegetation management and as a relatively liquid asset which can be utilized to improve financial stability (Siegmund-Schultze et al., 2007) especially for smallholder farmers.

Though uniquely positioned to benefit all three components of sustainable production, i.e. the environment, economy and society, if not appropriately managed these benefits of beef production may be squandered and/or reversed. Examples of potentially unfavorable impacts of the beef industry include: making inefficient use of human-edible foods, overgrazing arable/non-arable land to the point of permanent degradation and increasing on-farm capital risk. Additionally, adverse effects of an intensified focus on increasing efficiency of production are discussed by Rauw et al. (1998). Citing instances in broiler, pig and dairy production, they suggest that intensifying genetic selection for increased productivity in the livestock sector has the potential to disturb what Siegel (1995) refers to as the animal's "homeostatic balance," 
which could potentially lead to, "increased susceptibility to disease, impaired reproduction or inefficient metabolism, and thus impaired animal welfare" (Rauw, 1998). For example, due to commercial turkey breeder's focus on growth rates (McCartney et al., 1968) the average live weights of turkeys in the U.S. increased by 4 kg between 1960 and 1995 (Rauw, 1998). Today, breeding of U.S. turkeys is 100\% accomplished by artificial insemination performed by humans because natural mating is too difficult for the birds that have continuously been selected for superior growth. Intensified focus on growth of commercial turkeys have rendered the birds incapable of persisting without continued human intervention, a fact not well received in mainstream media (Butler, 2014).

The U.S. turkey example illuminates a few caveats to genetic selection for increased productivity 1) that increased focus on production outcomes may come at a cost to other biological functions, 2) that the production traits selected for may alter the necessary support for a resource-limited environment in which those production traits are realized 3) there may be social ramifications related to production decisions. As such, Rauw et al. (1998) caution that economic wins in production traits should not come at a cost of biological successes. They also suggest solutions such as selecting for more than just production traits. In practice, this looks like selection for temperament. They also suggest efforts towards better understanding of the "underlying physiological processes," that genetic selections impact. 
Significance of energy exchanges in the beef industry

Cow-calf production systems ideally produce a healthy and productive weaned calf at the rate of one calf per cow per year. Feed costs, a significant source of energy input in beef production, represent the largest variable cost in cow-calf production systems (Miller et al., 2001) and nutrition is the biggest driver of successful reproduction (Roche, 2006). U.S. cow-calf production systems are typically extensive, and are based on grazing/forage (Pelletier et al., 2010). These systems depend on forage growth and availability to provide the caloric supply necessary to maintain cows and to support the growth and health of the calves born to and raised by them. Consequently, uncontrollable/unpredictable reductions in forage availability, for instance, due to drought, which vary in severity across regions and time (Panu and Sharma, 2002), may unfavorably impact beef production by reducing the energy available for meeting animal requirements.

Severe drought across the southern plains of the U.S. starting in 2011, compelled producers to sell more of their feeder cattle at lighter weights than traditionally practiced. This spike in the supply of light-weight feeder cattle, especially in the 2012 and 2013 markets, reduced prices paid to producers for these feeders (USDA, 2012). This same drought was a contributing factor to a decrease in cow herd numbers across the Great Plains by 11-14\% in 2012 (Paterson, 2014) which lead to a 60 year low for the U.S. cattle inventory (Schnepf, 2012) as grazing systems, at the time, could no longer meet the energetic requirements of the existing herd. A non-exhaustive list of other factors that contributed to the volatility of the beef market in the early 2010's included: a 
previous drought in the Southeast of the U.S. (NASA, 2007), increasing prices for real estate across the country (USDA, National Agriculture Statistics Services, 2015) which increased production costs, decreases in the number of cow/calf operations, cattle feeders and beef packers in the U.S. (Kester, 2003), changes in the international export of U.S. beef as a result of the 2003 Bovine Spongiform Encephalopathy event (Miller, 2012), increased production from international competitors (Miller, 2012).

The response of beef production to the 2011 drought and overall industry climate, exemplifies the industry's, at least short-term, inability to endure or maintain supply with changes in grazing forage availability which illuminates inherent risk to the industry.

Inability to maintain production burdens the economic health of the industry, and contributes to global price volatility (Subervie, 2008). Changes in an agricultural commodity's supply and subsequent impacts of this change on the price and aggregate demand of that product are often first demonstrated at the household, then country, and then global level (Collier, 2002). Expectedly, households were presented with record high prices for beef during 2012 following the aforementioned multifactorial shrinkage of the U.S. beef herd (Schnepf, 2012) which, due to the elastic nature of beef demand, reduced demand for the product (Schroeder et al., 2000). When beef prices exceed consumer's willingness to pay threshold, consumers may be impelled to purchase other proteins such as pork or poultry instead (Marsh, 2013). Further, a reduction in beef's share of the animal protein market would represent a missed profit opportunity 
associated with the growing global middle class' propensity to increase its protein consumption (Hansen and Gale, 2014).

Using less production inputs, or energy, is something producers are generally motivated to work towards. Also, the aforementioned Great Plains drought and its immediate market effects, in combination with the implications of permanent loss in forage availability following prolonged periods of disturbance, intensified the pursuit of non-forage dependent cattle feeding strategies. Alternative approaches to managing energy supply and producing beef, which can withstand and/or which introduce reduced input use, merit investigation. One such approach involves limit-feeding highconcentrate diets to cows in confinement for part or all of their production cycle. Researchers supposed that this feeding approach could mitigate risk associated with unreliable forage availability, reduce capitalization requirements, and incentivize heard expansion for producers (Trubenbach, 2014). Based on those merits, they investigated limit-feeding in confinement's effect on nutrient utilization and maintenance energy requirements in mid-gestation cows (Trubenbach, 2014). They found that increasing energy density while simultaneously decreasing total intake decreased energy lost from the cow as heat. The limit feeding studies by Trubenbach (2014) and Boardman (2015) were investigated using mature cows in their second-trimester of gestation, given the significant differences between the gestational trimesters of a beef cow, especially in terms of energy allocation, each stage warrants independent research. However, their work suggests that with the right management practices in place, limited forage use 
could represent a win for the "energy balance sheet" of beef production rather than a symbol of impending loss in production.

Energetic profit provided to society by the beef industry is highly dependent on the cattle feeding strategy and ensuing efficiency of feed conversion (Oltjen \& Beckett, 1996). A complete life cycle assessment of the beef industry between 2005 and 2011 determined that nearly 80 percent of the industry's energy use was in the form of animal feed (NCBA, 2014). Increasing the efficiency of the beef industry through carefully and intentionally managed feeding methodologies is both feasible and worthy of study (Bradford, 1999). Ultimately though, optimizing beef production's energetic profits requires measuring the circumambient inputs and outputs at all levels of the production cycle.

Currently the NRC (2000) uses Garrett and Lofgreen's (1968) net energy system to delineate energy values in beef cattle. A NE analysis initiates with quantifying the energetic inputs, which in the case of a beef animal are the feedstuffs the animal consumes. Gross energy (GE) describes the energy of an organic substance released as heat in response to combustion (complete oxidation). It does not appropriately quantify the energetic value of a feedstuff in terms of energy available to the animal because it does not account for the energetic losses that accompany nutrient digestion and metabolism in living organisms. Digestible energy (DE) accounts for intake energy losses associated with fecal energy. Additional whole-system energetic losses as animals utilize nutrients, including urinary energy and gaseous energy losses are subtracted from $\mathrm{DE}$ and what is left is the metabolizable energy (ME) available to the animal. Energy 
metabolized by an animal results in either heat energy (HE) released (i.e. lost) from the animal or retained energy $(\mathrm{RE})$, such that $\mathrm{ME}=\mathrm{RE}+\mathrm{HE}$. Energy from $\mathrm{ME}$ not lost to $\mathrm{HE}$, referred to as retained energy is utilized by the animal differently depending multiple biological variables (e.g. breed, sex, stress) and the animal's production status (e.g. lactation, pregnant; NRC, 2000).

Maintenance energy requirements represent the total amount of energy used for basal metabolism that is lost as heat when the animal is fasting, referred to as fasting heat production (FHP), plus the heat of activity and additional energy lost when the animal consumes a level of feed sufficient to maintain body energy content referred to as heat increment. As an equation, metabolizable energy for maintenance $(\mathrm{MEm})=\mathrm{FHP}+$ heat associated with voluntary activity $(\mathrm{HjE})+$ the heat increment of feeding $(\mathrm{HiE})$; (McBride and Kelly, 1990). An animal's FHP is a measure of that animal's basal metabolism. Basal metabolism is the energy required to sustain life processes such as vital cellular activity, and the circulation of blood and oxygen.

Contributions to energy expenditure in beef cattle

Energy expenditure necessary to maintain a beef animal is significant. Of the entire beef production cycle, 60-70\% of total energy expended is used for maintenance functions (Ferrell, 1988). Accordingly, input energy provided for maintenance, in the form of feed, represents a major cost of production. Maintenance energy requirements must be met before nutrients may be utilized for deposition of gain, gain that leads to beef products and, ultimately, profit. In addition to scientific intrigue, this large economic element makes explaining and potentially reducing the energy expenditure 
associated with maintenance, a topic of interest for many of the beef industry's stakeholders. As in the iron, steel and other industries described earlier, decision support tools and other endeavors that inform the most efficient way(s) for the beef industry to realize energetic profits, that go beyond the overhead-like costs of a beef animal's maintenance energy requirements is essential. Therefore, an understanding of contributors to the maintenance energy requirements of beef is key and the thus the following potential contributors will be discussed: body composition and the mass and metabolic activity of highly metabolic organs with particular focus on the liver.

It would be a reasonable presumption to attribute variations in maintenance energy expenditure to variations in an animal's body composition. However, research has demonstrated that the cause and effect links may not be so straight forward. Ferrell et al., (1986) fed lambs to realize different live weight gains. Fasting heat production was determined and lambs were subsequently harvested. Lamb organ weights and body composition (fat to lean ratio) at slaughter were recorded. Lambs fed to gain more live BW had correspondingly greater empty BW and chemical tissue components (water, fat, protein and ash) but the lambs on the lower gain treatment had a greater protein to fat ratio. Fasting heat production levels differed among animals with similar live weight gain and empty body chemical composition. Lambs that had significantly different gains and composition of gain did not have differences in NEm requirements. This result would not be expected if FHP expenditure were a function of body composition. Vermorel et al. (1976) observed no difference in energy expenditure between doublemuscled and normal muscled Charolais bulls. These findings support the conclusions 
that noted changes in FHP, or NEm, are not due to differences in chemical body composition nor composition of weight gain.

In the discussion of potential influences to variations in whole-animal energy expenditures, there is noteworthy data pointing to visceral organ energy expenditure (Ferrell, 1988). The liver is a highly metabolic organ and therefore highly active in energy exchange in an animal. Energy use by the liver has been estimated by Johnson et al. (1990) to account for $45-50 \%$ of whole-animal heat energy. Biochemical processes of the liver are influenced by diet composition and intake level, age, endocrine status, and physiological state (McBride and Kelly, 1990). Therefore, a look into these factors and their interactions is an important lens from which to view the energetic expenditures of the liver and its contributions to whole-animal energy expenditure.

Cañas et al. (1982) investigated the effect of physiological status changes on energy expenditure changes in rats, primarily focusing on why maintenance energy requirements tend to escalate during gestation and lactation. They considered two possibilities for this occurrence: First, that increases in the metabolic rates of tissues during gestation and lactation are due to altered nutrient intake and hormone levels (associated with pregnancy); and second, that increases in the proportional weights of highly metabolic organs cause increases in whole body energy expenditure per unit of body weight. Metabolic activity of an organ is referred to as the product of an organ's size and the metabolic activity per unit of tissue of that organ (Burrin et al., 1990), such that increases in total energy expenditure may result from increases in organ size, increases in metabolic activity per unit, or both. 
To address the effects of gestation and lactation on the metabolic activities of tissues, rats were split into four different treatment groups with ten rats in each: virgin, pregnant, early lactation and late lactation. All rats were fed ad libitum. Pregnant rats were $19 \mathrm{~d}$ pregnant when harvested. Early lactation rats were harvested on $\mathrm{d} 3$ of lactation and the late group on d 19 of lactation. At harvesting, liver, heart and digestive tracts were removed and weighed and then the metabolic activities of these organs were measured from samples. When compared to non-pregnant and non-lactating rats, oxidation of glucose, palmitate and pyruvate by the liver, heart and intestines were 1.5 times greater for gestating rats and 3 times greater for lactating rats indicating that elevated maintenance energy requirements during gestation and lactation might be attributed, in some degree, to an increase in energy use per unit of organ mass.

There was some evidence that thyroxine, a thyroid produced hormone known to be involved in the regulation of metabolism (Danforth and Burger, 1984), may have initiated the increases in oxidation. Other studies have supported the notion of increased levels of thyroxine during gestation and lactation. For example, thyroxine levels of lactating cows (Anderson and Bauman, 1968) were four times higher than those of heifers. Sibai and Frangieh (1995) found elevated levels of total thyroxine concentrations and thyroxine stimulating hormone in serum from pregnant humans, but suggest that levels of free thyroxine during pregnancy is controversial. In more recent findings, Araujo et al. (2010)concur that thyroid hormones impact the oxygen consumption of different organs and tissues and that these may result in changes in animal's metabolic rates. 
In the portion of the study investigating impacts of intake level on relative masses of the liver, heart and intestines, forty lactating and nonlactating rats were fed at varying intake levels for one week. After the rats in each group were harvested, all gastrointestinal tracts, livers and hearts were removed and weighed. Lactating rats consuming twice the amount of feed consumed by non-lactating rats had heavier livers, hearts and intestine. It's important to note that, due to their highly metabolic nature, these organs require more energy expenditure when compared to other essential organs (Huntington, 1990) and when their masses increase so does their energy expenditure. In summary, Cañas et al. (1982), suggest that increases in the metabolic rates and weights (as impacted by increased intake) of highly metabolic organs, observed in gestating and lactating rats contribute to an explanation of the increased maintenance energy requirements associated with these rats when compared to open and non-lactating rats. However, Burrin et al. (1988) determined that whole-animal energy expenditure of fasted rats was not a result of a reduced ME use per unit of liver tissue, but rather a result of a reduction in total liver mass. As such, the impacts of liver size on whole-animal energy expenditure will be discussed further.

Johnson et al. (1990) conducted four sheep studies, two steer studies and a Holstein cow study. Animals in each study were fed at different ME intake levels, each of which remained constant for at least twenty-one days prior to slaughtering of the animals. Following treatment and slaughter, relationships among visceral organ growth and diets were examined. In order to compare organ weights across studies, the weights were expressed as their ratio to empty body weight $(\mathrm{kg})$ raised to the three-quarter power 
i.e., liver weight per unit of metabolic BW. The livers of growing steers and sheep fed at their NRC predicted maintenance levels weighed 40 and $30 \mathrm{~g} / \mathrm{kg} \mathrm{MBW}$, respectively. Comparatively, similar animals that had been fed above their maintenance requirements, had livers that weighed 60 and $50 \mathrm{~g} / \mathrm{MBW}$ when slaughtered. With the use of similar techniques and data expression, the liver mass per MBW of lactating cows fed above their maintenance energy requirements was 2 -fold greater than those fed at maintenance.

In the same study by Johnson et al. (1990), organ weight alterations per unit of diet alteration were similar across sheep, steer, and lactating cow studies. Liver weights increased, on average, $29 \mathrm{~g}$ per dietary ME increase of $0.24 \mathrm{Mcal}$. When diet compositions alone were changed, in other words metabolizable intake was held constant but the source of it was changed, the results did not differ. Animals fed at a higher plane of nutrition, regardless of source exhibited larger liver weights. They concluded that liver mass increases about $15 \mathrm{~g}$ per $\mathrm{kg}$ MBW for each $1 \times$ maintenance increase in ME intake. They characterized such changes in metabolizable energy intake as an explanation for changes in mass, and resulting changes in energy consumption of the liver.

Smith and Baldwin (1974) investigated the effects of dairy cattle breed, pregnancy and lactation status on the weight of cow organs and tissues. Holstein (25 head, 15 lactating and 10 nonlactating) and Jersey (23 head, 7 lactating, 9 non-pregnant and nonlactating and 7 pregnant nonlactating) cows were incorporated into the study. As no differences were found due to pregnancy status in nonlactating cows, data from these animals was combined. Whole body weights of animals involved in the study varied but 
absolute liver weights were greater in lactating cows than non-lactating cows of both breeds. Specifically, the liver of non-lactating cows was $1.30 \%$ of total body weight, whereas, in lactating cows the liver was estimated to account for $1.65 \%$ of total body weight. The demand for metabolic products are elevated in order to support lactation, and it is possible that this requires the highly metabolic liver to engorge.

In their study, (Reynolds et al., 2004) explained the liver needs to increase in capacity to meet lactation demands. They further investigated to conclude whether this increase in capacity is just a function of lactation, for example alterations of different hormone levels, or more specifically the changes in dry matter intake (DMI) associated with lactating animals. The control ration, given to all cows, was designed to meet $\mathrm{ME}$ and CP requirements of the cows. Non-control treatments included: no supplement, a protein supplement, or a barley meal supplement. Cows were individually fed using Calan-Broadbent electronic gates. Cows were scheduled to be harvested at different times ranging from twenty-one to seven days before their expected calving date and ten and twenty days after calving.

Cows harvested twenty-one days after calving had larger livers than cows harvest ten days after calving. As in other studies (Smith and Baldwin, 1974, Johnson et al., 1990, McLeod and Baldwin, 2000) changes in liver mass were dictated by changes in DMI. In this study, mass changes were not evident until twenty-one days postpartum, the same time at which intake of dry matter increased. Neither protein nor energy supplementation appeared to significantly affect visceral organ mass. Dry matter intake affected relative mass of the liver, not just the function of lactation. In conclusion, the 
increase in the capacity of the liver during lactation is a result in the increase of DM intake associated with lactation.

Ferrell (1988) explored the impact of changing liver mass on changes in lactating cow's FHP, suggesting a strong relationship between differences in liver weights and changes in daily heat production. This relationship indicates that liver mass changes may explain variations in total animal energy expenditures. The liver's contribution to total heat production in lactating cows was not reported. However, data reported for percent of total heat production for non-lactating cows was based on previous studies (Brody 1945, Bard 1961) and was reported as $22.5 \%$ of total heat production. They credited liver growth in lactating cows as a factor involved in increasing the maintenance requirements of these cows. Again, this growth in liver mass during lactation was attributed to changes in the level of DMI observed during lactation. The estimated effect of liver mass change on maintenance requirements was made assuming energy expenditures per kilogram of liver tissue were the same for both non-lactating and lactating cows.

Energy requirements are increased during lactation and gestation. This is significantly a result of the increase in total mass of the liver. Increases in liver mass in turn increase total energy use of the already highly metabolic organ.

Changing energy expenditure in beef cattle: increasing efficiency

Cows reliant on available pasture commonly gain and lose weight depending on forage quality and availability (Swingle et al., 1979; NRC 2000). To offset these fluctuations, cow-calf producers often provide additional supplementation when forage 
availability/quality is insufficient. Otherwise, cows unable to maintain adequate weight during calving, lactation, and rebreeding could be reproductively compromised (Selk et al., 1988; Hough et al., 1990; Freetly et al., 2000) and growth rates of calves born to these cows may be stunted (Corah et al., 1975). However, strategically designing periods of limit-feeding and re-alimentation during the cow's production cycle has demonstrated energetic advantages (Freetly and Nienaber, 1998, Freetly et al., 2008, Trubenbach, 2014) in mature cows. These advantages are primarily observed as a reduced energetic loss to heat production during digestion and metabolism (Freetly and Nienaber, 1998; Trubenbach, 2014) in energy restricted cows.

In a study on growing heifers fed isonitrogenous, pelleted, diets of either $75 \%$ concentrate or $75 \%$ alfalfa, heifers fed the greater proportion of concentrate produced less heat, methane and retained more body tissue (Reynolds et al., 1991). The portaldrained viscera (PDV) of the heifers fed $75 \%$ alfalfa tended to require greater blood flow, which was ascribed to greater $\mathrm{O}_{2}$ consumption of those heifer's PDV. To keep the treatments at equal ME intake, heifers fed the $75 \%$ alfalfa diets consumed more DM than heifers fed the $75 \%$ concentrate diet which was reported to have induced the differences in PDV activity, heat production, and utilization of ME for tissue retention between the alfalfa fed and concentrate fed heifers. However, due to confounding effects, sussing out whether these results were due to the differences in the energy density or DMI across treatments is nearly impossible. In summary, feeding energetically dense, highconcentrate diets facilitates reduced DMI, improved efficiency of energy utilization and reduces maintenance energy requirements. 
In addition to inaugurating energetic savings at the individual cow and whole system levels, limit-feeding, high-concentrate diets to cows in confinement for a portion of their production cycle may be an economically and logistically attractive option. Baber et al. (2016) fed 3 treatment rations for $112 \mathrm{~d}$ : a TMR, TMR with the hay and concentrate portions fed $12 \mathrm{~h}$ apart, and an ad libitum Bermuda grass hay to mid- to lategestation beef cows. The TMR and the separated TMR were limit fed at $80 \%$ of the cow's NRC-predicted requirements for maintenance. There were no differences in final cow BW or BCS; however, the cows on the limit-fed rations retained more energy than the cows fed ad libitum hay. She concluded that limit-fed, high-concentrate rations can be parsed into hay and concentrate portions fed separately, without compromising cow performance. This feeding strategy alleviates energetic and monetary costs associated with mixing a TMR as well as concerns of over-mixing which may be problematic if particle sizes become too small and hinders rumen function (Allen, 1997). If producers were equipped with alternative feeding strategies, they may be able to preserve total cow numbers during times of drought or other arduous circumstances. Additionally, and perhaps of greater importance than maintaining total cow numbers, is maintaining the U.S. beef supply by optimizing the productivity of those cows and their annual calf-crop. Energy exchange from dam to calf

After 5-6 days of mitotic cellular division, which is initiated by fertilization of a cow's oocyte, the bovine embryo travels from the oviduct to the uterus. Maternal recognition of the pregnancy occurs between 15 and 17 days after fertilization, followed by placental attachment to the uterus that occurs between 18 and 22 days post 
fertilization. The placenta and uterus attach at isolated locations referred to as caruncles. As the metabolic demands of the bovine conceptus increase throughout its approximately 283 day gestation, the vasculature of the caruncles continues to develop. Adequate growth and development of the utero-placental connection is extremely important to the viability and productivity of the bovine fetus, as it is the organ through which respiratory gases, nutrients and wastes are exchanged between dam and conceptus (Reynolds \& Redmer, 1995). Most of the growth of the placental interface occurs during the first half of gestation, whereas $75 \%$ of calf growth occurs during the third trimester; however, if placental transport capacity (i.e. blood flow) does not keep pace with the fetus, fetal growth will be compromised (Reynolds and Redmer, 1995).

Fetal growth is influenced by genetics yet limited by the uterine environment, specifically the nutrient and oxygen flow from dam to fetus. Fetal programming describes the process whereby a "stimulus or insult during a critical period of development [in utero] has lasting or lifelong effects,"(Godfrey and Barker, 2000). Maternal nutrition has been shown to have long-term effects on human and animal offspring (Bellows and Short, 1978; Barker et al., 1993; Godfrey et al., 1996; Freetly et al., 2000; Whorwood et al., 2001); however, mechanisms by which nutrient prompted changes in fetal programming, resulting in observed post-natal impacts, are not fully elucidated.

One well-understood process with lasting impacts on calf health is colostrogenesis, or the process by which immunoglobulins are transported from the dam's blood to specified IgG receptors in her mammary glands, which begins several 
weeks before parturition (Weaver et al., 2000). This biological occurrence may help to explain the increased protein requirements which characterize the final two months of a cow's pregnancy (Quigley and Drewry, 1998); Up to 500g of IgG are transported via selective transfer from maternal circulation to the mammary system during each week of colostrogenesis (Barrington et al., 2001), such that the colostrum has a five-fold greater concentration of $\operatorname{IgG}$ compared to the dam's serum $\operatorname{IgG}$ levels. As a frame of reference, maximum fetal growth, which occurs on d 230 of gestation (Eley et al., 1978; Prior and Laster, 1979) was reported by Eley et al. (1978) as $220 \mathrm{~g} / \mathrm{d}$ and as $352 \mathrm{~g} / \mathrm{d}$ by Prior and Laster (1979).

In addition to IgG proteins, colostrum is densely packed with essential macromolecules including fats, proteins, carbohydrates, growth factors, hormones, minerals, vitamins and other immunoglobulins. Protease inhibitors in colostrum reduce protein degradation (Pácha, 2000) so that proteins, such as IgG, can be absorbed intact from the dam by the calf.

The presence of multiple placental barrier layers inhibits placental transfer of maternal antibodies between cow and calf (Chucri et al., 2010), rendering the immune system of the newborn partially inactive. As such, the calf relies on a period of passive immunity acquired via immunoglobulin transfer from colostrum its dam's immune system post-parturition. Successful colostrogenesis is the critical first-step for the passive immune transfer from dam to calf and ultimately the survivability of the young ruminant (Barrington et al., 2001). The second imperative step is accomplished by the calves' ingestion of colostral macromolecules which may penetrate the calf's intestinal 
epithelium for approximately $24 \mathrm{~h}$ postpartum, with optimal transfer occurring in the first $4 \mathrm{~h}$. Following ingestion, macromolecules including IgG enter the calf's circulatory system via the thoracic duct.

To provide efficient absorption and utilization of colostral macromolecules, it is suggested that the calf ingest at least $100 \mathrm{~g}$ of colostral IgG within the first 4 hours of life (Barrington et al., 2001). This time period is characterized by the animal's use of an esophageal groove, which allows ingested colostrum and milk to bypass the rumen and associated fermentation, permitting absorption of intact macromolecules later in the calf's gastrointestinal tract. Absorption of colostral macromolecules is facilitated by specific receptor-mediated and nonspecific transcytosis in the calf's intestinal epithelium (Pácha, 2000).

Failure of absorption and thus immune transfer can result in substantial losses in calf health, productivity and potentially life especially during the first $21 \mathrm{~d}$ of the calf's life (Wells et al., 1996). According to Weaver (2000), if passive immune transfer has been successful, peak serum IgG level occur 32 hours post-birth. Failed passive immune transfer was defined as calf serum IgG concentrations, measured between 24 and 48 hours of age, less than $10 \mathrm{mg} / \mathrm{mL}$ (Weaver et al., 2000) and as total protein levels below $5.2 \mathrm{~g} / \mathrm{dL}$ (Naylor and Kronfeld, 1977).

Hitherto, efforts to measure, and the resulting ability to manage, colostrum IgG levels have not been widespread in the beef industry, likely because calves are born in pastures with little if any human contact during their first few days of life. That said, colostrum IgG measurement techniques are increasing in on-farm ease and accuracy. 
Radial immunodiffusion assay laboratory assessment is referred to as the gold standard approach for measuring IgG concentration in bovine colostrum (Bielmann et al., 2010). However, this approach requires equipment and expertise often unavailable on-farm. As an alternative, estimating the colostrum IgG content by measuring the Brix percent of colostrum is an accepted approach during which the Brix percent of a liquid such as colostrum is measured utilizing a digital or optical refractometer. The refractometer works by passing light through a liquid and measuring the bend to that light created by the contents of the liquid. The amount of light bent by a colostrum sample, given in numbers on a Brix scale by a refractometer, have been shown to be highly correlated with the level of antibodies in the sample (Deelen et al., 2014).

Beilmann and associates (2010) compared the use of digital and optical refractometers against radial immunodiffusion (RID) assays to estimate colostrum IgG levels in frozen and fresh samples via 288 colostrum samples collected from 3 different dairies. They measured each colostrum sample four times and determined correlations between the different measurement techniques using correlation plots. No differences between fresh and frozen measurements using digital and optical refractometers were observed.

A correlation of $0.73(n=273)$ was observed between the RID and digital refractometer. A similar correlation of $0.71(\mathrm{n}=272)$ was noted between the RID and optical refractometer. When comparing samples read by the optical and digital refractometers, their correlations to the RID method appeared to be impacted by cow age. Samples from first calf heifers had the highest correlations between instruments 
ranging from 0.77 and $0.83(P<0.001 ; \mathrm{n}=272)$ followed by correlations between samples from cows in their third lactation or greater which ranged from 0.71 and 0.73 .

Colostrometers may also be used to estimate $\mathrm{IgG}$ concentration in colostrum and/or milk. Colostrometers measure the specific gravity of the sample which Fleenor and Stott (1980) reported as being highly correlated $(\mathrm{r}=.699)$ with the globulin content. However, unlike with digital and optical refractometers, the temperature of the sample will affect its readability. Use of a colostrometer also requires a full cup of sample whereas use of a refractometer may only require $1 \mathrm{~mL}$ of sample. Additionally, fat and/or non-IgG proteins present in the sample may impact the specific gravity reading

made by the colostrometer. The colostrometer and the refractometer alike may be useful, on-farm tools for beef producers interested in managing or investigating passive immune transfer between dams and calves on their operation.

\section{Overall summary}

For the beef industry to deliver an energetic profit to society, it is imperative, from a productivity standpoint, that nutrient or feed delivery during the beef cow's third trimester not hinder the ability of the dam to wean a competitively marketable calf each year. The third trimester is marked by significant increases in energy requirements for maintenance including metabolic output from the heart and liver (Freetly, 2008), growth of the fetus and gravid uterus (Moe and Tyrrell, 1972; Quigley and Drewry, 1998), a rapid increase in maternal heat production and an overall decrease in the use of ME for body tissue retention (Freetly et al., 2008). However, limit-feeding high-concentrate diets to beef cows in confinement during this production phase may be an energetically 
efficient option for the cow-calf sector. Exploration of this topic could yield data necessary to source energetic profits from the beef industry that support both producer's returns and consumer's dietary needs. 


\title{
CHAPTER II
}

\author{
EFFECT OF DIETARY ENERGY INTAKE ON NUTRIENT UTILIZATION, \\ PERFORMANCE, AND MAINTENANCE REQUIREMENTS IN LATE GESTATION \\ COWS AND THEIR CALVES
}

Synopsis

Sustainability of the U.S. cow-calf sector is vulnerable to drought and elevated land prices. Limit-feeding high-concentrate diets to cows in confinement may mitigate risk associated with unreliable forage availability and reduce capitalization requirements while increasing efficiency of nutrient utilization. Limit feeding was investigated using 60 multiparous, late-gestation beef cows (462 kg initial BW). Cows were blocked by BW and individually fed one of four treatments $(70,85,100$, and $115 \%$ of NRCpredicted maintenance energy) in Calan gates for an average of $71 \mathrm{~d}$ prior to calving. Diets consisted of $2.00 \mathrm{~kg}$ of wheat straw (2.5\% CP; $79 \% \mathrm{NDF})$ and one of four levels of a mixture of corn (45\%), distiller's grain (42\%) and premix (13\%) fed at 2.70, 3.41, 4.12, and $5.84 \mathrm{~kg} / \mathrm{d}$ to correspond with the $70,85,100$, and $115 \%$ treatments. Following calving, pairs were managed as a group on pasture. Digestion was determined using ADIA as an internal marker. Cows were weighed on days $0,22,52$, at parturition, at 60 , 90, 120 and 160 days post parturition, and at weaning (d 270). Cow body energy was estimated on days 0 and 52 using back fat values measured between the $12^{\text {th }}$ and $13^{\text {th }}$ rib via ultrasonography. Digestible energy intake increased linearly (5.92, 6.78, 7.77 and $8.86 \mathrm{Mcal} / \mathrm{d}$ for $70,85,100$, and $115 \% ; P<0.01)$ per design; ME intake responded similarly $(4.85,5.56,6.37$ and 7.26 Mcal/d). No effects $(P>0.05)$ on DM, OM, or GE 
digestion were observed; ADF digestion tended to decrease linearly $(P=0.07), \mathrm{DM}$ digestion averaged $62 \%$. Cow retained energy during the limit-feeding period ( 0 to 52) increased linearly $(P<0.01)$ from $46.6 \mathrm{Mcal}$ for $70 \%$ to $50.7,106.3$, and $123.8 \mathrm{Mcal}$ for 85,100 , and $115 \%$. Empty body weight gain increased linearly over the same time period $(P<0.01)$ from $0.7 \mathrm{~kg}$ for $70 \%$ to $3.6,17.7$, and $24.2 \mathrm{~kg}$ for 85,100 , and $115 \%$. Calf birth weight increased linearly $(P=0.01)$ from $32.5 \mathrm{~kg}$ for $70 \%$ to $35.5,35.2$, and $36.8 \mathrm{~kg}$ for 85,100 , and $115 \%$. Brix (\%) values for colostrum at parturition did not differ $(P \geq 0.14)$ as a result of dietary treatment and at $24 \mathrm{~h}$ post parturition showed a cubic response $(P=0.03)$. Immunoglobulin $\mathrm{G}$ levels in calf serum collected at birth, $24 \mathrm{~h}$ and $7 \mathrm{~d}$ did not differ among treatments $(P>0.05)$ and averaged $47,4,749$, and 4,464 $\mathrm{mg} / \mathrm{dL}$, respectively. Cow body weights remained greater (linear, $P<0.05$ ) in cows fed increasing levels of energy at days 60 and 90 post parturition, tended to be greater $(P=$ $0.09)$ at $\mathrm{d} 120$, but no longer differed $(P \geq 0.33)$ at 160 days post parturition or at weaning (d 270). Level of energy intake during gestation did not result in significant differences $(P>0.05)$ in calf weights at $60,90,120$ or 160 days post parturition or at weaning (averaged $206 \mathrm{~kg}$ ). Cow 30 and $60 \mathrm{~d}$ conception rates were $82 \%$ and 98\%, respectively and did not differ across treatments. Production goals of the cow-calf sector were successfully met by limit-feeding late-gestation beef cows at intake levels at least $70 \%$ of NRC-predicted energy requirements for maintenance.

\section{Introduction}

Sustainability efforts for many businesses and industries across the globe are aimed at more than good citizenship and positive public relations. They are efforts to 
secure a competitive advantage and/or remain afloat in highly saturated markets and shrinking profit margins. In a study including 99 companies from 18 different industries, the companies operating sustainability strategies, defined as those, "geared toward protecting the environment and promoting social well-being while achieving shareholder value," are securing average returns 15\% greater than their peers (Winners, 2009). Agriculture is hearing the same, sustainability-focused, call to action. With a charge to meet the nutritional demands of approximately 9 billion people requiring a 50\% increase in demand for food by 2050 (Godfray et al., 2010; Alexandratos and Bruinsma, 2012) - maintaining and/or increasing production yields, enduring impediments, and achieving optimized impacts on the global environment, economy and society are an undeniable expectation (Tilman et al., 2002). Beef as a source of highquality, human-edible protein aims to contribute to meeting global requirements; however, doing so in an unsustainable manner would be fiscally and socially irresponsible. To that end, the US beef industry improved sustainability across the entire beef production life-cycle by 5 percent between the years 2005 and 2011 (Cattlemen's Beef Board and National Cattlemen's Beef Association, 2014).

Preserving beef production as a profitable enterprise for producers and attainable product for consumers is challenged by factors such as: uncertain forage availability, rebuilding of the US cow-herd following a severe drought-induced liquidation, and increasing land prices. Limit-feeding cows in confinement, for all or part of their lifecycle, provides a strategic response to these challenges. Further benefits of an intensified feeding model include a reduction of energy required for cow maintenance and the 
opportunity to increase the number of mature cows an operation can support (Sawyer, 2015). The goal of this study is to investigate the reproductive and growth performance, nutrient utilization, and maintenance requirements of late-gestation beef cows as they are affected by limited intake of high-concentrate diets. Data will be used to determine the effectiveness of diet delivery systems in the cow-calf sector to provide productive returns on feed investments. By taking a systematic approach to the research, data collected can be used to improve the economic, environmental, and social sustainability of beef production.

\section{Materials and methods}

The experimental protocol involving the use of live animals was approved by Texas A\&M University's Institutional Animal Care and Use Committee for research conducted at the Animal Science Complex for Teaching, Extension, and Research (ASTREC) in College Station, TX.

Sixty, multiparous beef cows ( $3 / 4$ Bos taurus, $1 / 4$ Bos indicus; $3-14 \mathrm{yr})$ confirmed to be in late-gestation pregnancy, via ultrasound using an Aloka 500 ultrasound console (Hitachi Aloka Medical, Ltd., Wallingford, CT), and in good health were used in an experiment to investigate the effects of dietary energy intake on nutrient utilization, performance, and maintenance requirements in late gestation cows and their calves. The experiment was arranged in a complete block design with four treatments of 15 cows each. Cows were stratified by initial BW (462 kg) and assigned to 15 pens of 4 head each. Treatments consisted of four levels of net energy (NE) intake of a total mixed ration (TMR) provided to supply: 70, 85, 100, and 115\% of NRC-predicted maintenance 
energy requirements. Predicted energy requirements for maintenance were calculated using the NRC (2000) model estimates and the mean BW of cows $26 \mathrm{~d}$ prior to treatment application.

Diets consisted of $2.00 \mathrm{~kg}$ of wheat straw $(2.5 \% \mathrm{CP} ; 79 \% \mathrm{NDF})$ and one of four levels of a mixture of corn (45\%), distiller's grain (42\%) and premix (13\%) fed at 2.89, $3.67,4.46$, and $5.28 \mathrm{~kg} / \mathrm{d}$ to correspond with the $70,85,100$, and $115 \%$ treatments (Table 2.1). Cows were observed for health and individually fed in Calan gates (American Calan Inc., Northwood, NH) at approximately 0600h daily for an average of $71 \mathrm{~d}$ prior to calving. Feed refusals (orts), if present, were collected daily at 0600h prior to feeding. Cows had ad libitum access to fresh water throughout the entire experiment. At calving, pairs were moved to their own pen for $24 \mathrm{~h}$, after which, pairs were managed as a group on a pasture supplemented with Bermudagrass (Cynodon dactylon) hay provided ad libitum.

Cows were adapted to the Calan gate feeding system for at least $22 \mathrm{~d}$ prior to the onset of treatments. Pens were $6 \mathrm{~m}$ wide $\times 12 \mathrm{~m}$ long, and equipped with six individual feeding Calan gates, $1 \mathrm{~m}$ wide $\times 1.5 \mathrm{~m}$ tall and a float-controlled continuous water trough approximately $1 \mathrm{~m}$ long $\times 0.5 \mathrm{~m}$ wide and $0.15 \mathrm{~m}$ deep. The front one-third of the pens containing the feed bunks was covered by a pole barn. Continuous low-level lighting was used in the center of the barn to facilitate sample collection and project management. Pens were cleaned once per week. 
Table 2.1. Formulated ingredient and nutrient composition of treatment diets ${ }^{1}$

\begin{tabular}{|c|c|c|c|c|}
\hline & \multicolumn{4}{|c|}{ Treatment $^{2}$} \\
\hline & 70 & 85 & 100 & 115 \\
\hline Ingredient & \multicolumn{4}{|c|}{$\%$ As fed } \\
\hline Wheat straw & 44.84 & 39.06 & 34.52 & 31.04 \\
\hline Cracked corn & 24.81 & 27.40 & 29.46 & 28.92 \\
\hline Dried distillers' grains & 23.13 & 25.60 & 27.46 & 31.02 \\
\hline Urea & 0.93 & 1.00 & 1.10 & 1.16 \\
\hline Molasses & 4.21 & 4.70 & 5.00 & 5.27 \\
\hline Mineral $^{3}$ & 2.07 & 2.30 & 2.46 & 2.59 \\
\hline Diet components & \multicolumn{4}{|c|}{ DM basis } \\
\hline $\mathrm{CP}, \%$ & 14.47 & 15.62 & 16.53 & 17.20 \\
\hline TDN, \% & 53.28 & 56.36 & 58.70 & 60.62 \\
\hline ME, Mcal/kg & 2.32 & 2.40 & 2.47 & 2.52 \\
\hline $\mathrm{NE}_{\mathrm{m}}, \mathrm{Mcal} / \mathrm{kg}$ & 1.42 & 1.50 & 1.56 & 1.61 \\
\hline
\end{tabular}

${ }^{1}$ According to NRC (2000) model estimates.

${ }^{2} 70=$ received $70 \%$ NRC requirements; $85=$ received $85 \%$ NRC requirements;

$100=$ received $100 \%$ NRC requirements; $115=$ received $115 \%$ NRC requirements.

${ }^{3}$ Purina Wind and Rain All Season 7.5: Calcium (Min) $14.00 \%$ Calcium (Max) 16.00

$\%$ Copper (Min) 2,500 PPM Iodine (Min) 60 PPM Phosphorus (Min) $7.50 \%$

Selenium (Min) 27 PPM Salt (Min) $19.00 \%$ Salt (Max) $21.00 \%$ Zinc (Min) 7,500

PPM Magnesium (Min) $1.00 \%$ Potassium (Min) $1.00 \%$ Manganese (Min) 4,000

PPM Cobalt (Min) 12 PPM Vitamin A (Min) 150,000 IU/LB Vitamin D (Min) 15,000

IU/LB Vitamin E (Min) 150 IU/LB. 
On $\mathrm{d} 0$, prior to diet consumption, the following initial (pre-treatment) measurements were collected: body weight, body condition score (BCS), and ultrasonography measurements of intramuscular fat, ribeye area and fat thickness of the rump and ribs (between the $12^{\text {th }}$ and $13^{\text {th }}$ rib). Due to the unpredictable nature of calving date and the work from Swingle et al. (1979), Sawyer et al. (2004) and Trubenbach (2014), day 52 was selected for collection of final measurements which were the same as those mentioned above.

Body weights and BCS were also determined on d $-26,-10,0,22$, at calving, and at 60,90, 120 and 160 days post-calving and at weaning. Body conditions scores were determined via visual assessment and based on the guidelines discussed by Richards et al. (1986). Three independent visual assessment scores, from a 9-point scale, were averaged and utilized in the data analysis of this study.

Diet samples, of concentrate and hay sampled separately, were collected daily at $0700 \mathrm{~h}$, and equal daily amounts were composited weekly for subsequent analysis. Diet samples collected on days 43, 44, and 45 were analyzed for acid detergent-insoluble ash (Van Soest et al., 1991), the internal marker utilized to measure digestion. Six cows per treatment group were randomly selected for fecal collection to determine digestion. Fecal grab samples of $100 \mathrm{~g}$ each were collected and immediately frozen on days 43,44 and 45. Samples collected on day 43 at 0400 and 1600, on day 44 at 0800 and 2000, and on day 45 at 1200 and 2400 . Fecal grab samples were composited on an equal weight $(100 \mathrm{~g})$ basis within cow and a representative subsample, of approximately $500 \mathrm{~g}$ of the composite was retained for subsequent analysis. 
On-farm colostrum IgG concentration was measured using a Brix refractometer (Atago, Bellevue, WA) at calving and $24 \pm 3 \mathrm{~h}$ post-partum. Calf weights were measured and recorded at birth, and 60,90,120 and $160 \mathrm{~d}$ post birth and at weaning. Blood samples were drawn from calves within $3 \mathrm{~h}$ of calving and prior to nursing, at $24 \pm 3 \mathrm{~h}$ and $7 \mathrm{~d}$ post-partum. Upon collection, whole blood samples sat at room temperature for 30 minutes and were then centrifuged for $15 \mathrm{~min}$ at $1300 \times g$ (approximately 2,900 rpm). Serum was aliquoted into microcentrifuge tubes and placed in a $-20^{\circ} \mathrm{C}$ freezer until ready for analysis. Serum samples were sent to Texas A\&M Veterinary Medical Diagnostic Laboratory (TVMDL) to measure total $\mathrm{IgG}$ count.

On d 131, two Hereford bulls, of 2 and four years of age were put in a common pasture with the cows from the study to facilitate live breeding of the cows. On d 194, approximately 60 days after the cows were first exposed to the bulls, $3 \mathrm{ml}$ of whole blood was drawn from the jugular vein of the cows. The whole blood was immediately sent to TVMDL for measurement of pregnancy specific binding protein (PSBP) levels in each sample. Cows were deemed pregnant when their PSBP levels measured greater than $1.6 \mathrm{ng} / \mathrm{ml}$. Bulls were removed on d 194. On d 230, $3 \mathrm{ml}$ of whole blood was drawn from cows not previously deemed pregnant and analyzed as previously described.

\section{Laboratory analysis}

Fecal and feed samples were similarly processed and analyzed. All samples were dried at $55^{\circ} \mathrm{C}$ in a forced-air oven for $96 \mathrm{~h}$ and then allowed to air equilibrate before being weighed again to determine partial DM. Samples were then ground through a 1mm screen using a Wiley mill (Thomas Scientific, Swedesboro, NJ) and then analyzed 
for laboratory $\mathrm{DM}$ after being dried at $105^{\circ} \mathrm{C}$ for $16 \mathrm{~h}$ and $\mathrm{OM}$ was determined as the loss in dry weight on combustion at $405^{\circ} \mathrm{C}$ (Undersander et al., 1993). Analysis for ADF was performed using an Ankom Fiber Analyzer with sodium sulfite and amylase omitted and without correction for residual ash (Ankom Technology Corp., Macedon, NY). Acid detergent insoluble ash was determined by loss in ADF DM weight after combustion in a muffle furnace at $405^{\circ} \mathrm{C}$. Crude Protein $(\mathrm{CP})$ was calculated as $\mathrm{N} \times 6.25$, $\mathrm{N}$ being measured using an Elementar rapid N cube (Elementar, Hanua, Germany). Gross energy was determined using a Parr 6300 Bomb Calorimeter (Parr Instrument Company, Moline, IL).

Calculations

Digestibility of DM, OM, ADF and GE were each calculated using the following formula:

Digestibility $_{\mathrm{x}}, \%=\frac{\text { Intake }_{\mathrm{x}}-\mathrm{Fecal}_{\mathrm{x}}}{\text { Intake }_{\mathrm{x}}} \times 100 \%$

where:

Intake $_{\mathrm{x}}=\mathrm{DMI}(\mathrm{kg}) \times$ dietary nutrient concentration $(\% \mathrm{DM})$

Fecal $_{\mathrm{x}}=$ Fecal production $(\mathrm{kg}) \times$ fecal nutrient concentration $(\% \mathrm{DM})$

Fecal production was calculated by dividing ADIA consumption by fecal ADIA concentration:

Fecal production, $\mathrm{kg}=\frac{\operatorname{DMI} \times A D I A_{\mathrm{d}}}{\operatorname{ADIA}_{\mathrm{f}}}$

where:

DMI, kg

$\mathrm{ADIA}_{\mathrm{d}}=$ Dietary ADIA concentration $(\% \mathrm{DM})$ 


\section{$\mathrm{ADIA}_{\mathrm{f}}=$ Fecal ADIA concentration $(\% \mathrm{DM})$}

Digestible energy (DE) and metabolizable energy (ME) were calculated by the following equations:

$\mathrm{DE}(\mathrm{Mcal} / \mathrm{kg} \mathrm{DM})=\mathrm{GE} \times$ Digestibility $_{\mathrm{GE}}$

$\mathrm{ME}(\mathrm{Mcal} / \mathrm{kg} \mathrm{DM})=\mathrm{DE} \times 0.82$ per NRC $(2000)$.

Where:

Digestibility $_{\mathrm{GE}}=$ observed coefficient of energy digestibility $(\%)$

Body condition score (BCS) was calculated at the beginning and end of the preparturition limit-feeding period (d 0 and d 52) using a regression equation generated from observations of fat thickness corresponding to observed BCS (Herd and Sprott, 1986)

$$
\mathrm{BCS}=-1.2927 \mathrm{x}^{2}+6.0916 \mathrm{x}+2.2114
$$

where:

$\mathrm{x}=\mathrm{Rib}$ fat thickness $(\mathrm{cm})$ determined by ultrasonography

Equations published in NRC (2000) and Ferrell et al., (1976a) were used to calculate empty body energy.

Body energy (BE) was calculated as:

$$
\mathrm{BE}(\mathrm{Mcal})=(9.4 \times \mathrm{TF}+5.7 \times \mathrm{TP})-\mathrm{UE}
$$

Where:

$$
\begin{aligned}
& \mathrm{TF}=\text { total fat }, \mathrm{kg} \\
& \mathrm{TP}=\text { total protein }, \mathrm{kg} \\
& \mathrm{UE}=\text { gravid uterus gross energy, Mcal }
\end{aligned}
$$


Gravid uterus gross energy (UE) was calculated per NRC (2000) as:

$$
\mathrm{CBW} \times 1.811 \times \wedge((0.03233-(0.0000275 \times \mathrm{DG})) \times \mathrm{DG})
$$

Where:

$$
\begin{aligned}
& \mathrm{CBW}=\text { calf birth weight, } \mathrm{kg} \\
& \mathrm{DG}=\text { day of gestation }
\end{aligned}
$$

Body components were calculated as:

$$
\begin{aligned}
& \mathrm{TF}=\mathrm{AF} \times \mathrm{EBW} \\
& \mathrm{TP}=\mathrm{AP} \times \mathrm{EBW}
\end{aligned}
$$

Where:

$$
\begin{aligned}
& \mathrm{AF}=\text { proportion of empty body fat } \\
& \mathrm{AP}=\text { proportion of empty body protein } \\
& \mathrm{EBW}=\text { empty body weight, } \mathrm{kg}
\end{aligned}
$$

Body composition was estimated using the following equations:

$$
\begin{aligned}
& \mathrm{AF}=3.768 \times \mathrm{rBCS} \\
& \mathrm{AP}=20.09-0.668 \times \mathrm{rBCS} \\
& \mathrm{EBW}=(\mathrm{BW}-\mathrm{UF}) \times .96 \times .891
\end{aligned}
$$

Where:

$$
\begin{aligned}
& \text { BW = body weight, } \mathrm{kg} \\
& \mathrm{UF}=\text { Gravid uterus fresh weight, } \mathrm{kg}
\end{aligned}
$$

Gravid uterus fresh weight (UF) was calculated per Ferrell et al., (1976a) as:

$$
\left(743.9^{\wedge}((0.02-0.0000143 \times \mathrm{DG}) \times \mathrm{DG})\right.
$$

Where: 


$$
\mathrm{DG}=\text { day of gestation }
$$

Retained energy and HE were calculated as:

$\mathrm{RE}, \mathrm{Mcal}=\mathrm{BE}_{\mathrm{f}}-\mathrm{BE}_{\mathrm{i}}$

HE, Mcal $=$ MEI - RE

Where:

$$
\begin{aligned}
& \mathrm{BE}_{\mathrm{f}}=\text { total body energy on d } 52, \text { Mcal } \\
& \mathrm{BE}_{\mathrm{i}}=\text { total body energy on d } 0 \text {, Mcal } \\
& \mathrm{MEI}=\text { metabolizable energy intake, Mcal. }
\end{aligned}
$$

Maintenance level of intake for metabolizable energy $\left(\mathrm{ME}_{\mathrm{m}}\right)$ was calculated (per Trubenbach, (2014) for each of the four treatments using a linear regression of the means of RE on MEI. The linear functions representing each diet were solved for RE = zero; the solution of which represented $\mathrm{ME}_{\mathrm{m}}$ for the respective diet.

Fasting heat production was estimated for each treatment using the linear regression of the means of $\log (\mathrm{HE})$ on MEI. The linear functions representing each diet were solved for MEI = zero; the solution of which represented the estimate of FHP for each respective diet.

Statistical analysis

Conception rate data was analyzed using GLIMMIX procedure. All other data collected was analyzed using the PROC MIXED procedure of SAS 9.3 (SAS Institute, Inc., Cary, NC). Terms in the model included treatment, and pen. Treatment means were calculated using the LSMEAN option. Orthogonal polynomial contrasts (linear, quadratic and cubic) were used to partition treatment sums of squares. Statistical 
significance was considered at $\mathrm{P}<0.05$ and trends were considered between $\mathrm{P}=0.05$ and 0.10. Random effect was pen and model effect was treatment.

Results

Concentrate intake, total DM intake, and ADF intake increased linearly across treatments $(P<0.01$; Table 2.2). No effects $(P \geq 0.43)$ for DM, OM or GE digestion were observed; DM digestion averaged $62 \%$. There was a trend $(P=0.07)$ for a linear decrease in ADF digestion as energy intake increased. Digestible energy intake increased linearly $(5.92,6.78,7.77$ and $8.86 \mathrm{Mcal} / \mathrm{d}$ for $70,85,100$, and $115 \% ; P<$ $0.01)$ per design; ME intake responded similarly $(4.85,5.56,6.37$ and $7.26 \mathrm{Mcal} / \mathrm{d}$; Table 2.3).

Table 2.2 Apparent nutrient digestion of treatment diets fed to confined beef cows at four different levels of NRC predicted requirements for maintenance ${ }^{1}$

\begin{tabular}{lccccccccc}
\hline \hline & \multicolumn{4}{c}{ Treatment $^{2}$} & \multicolumn{5}{c}{ Contrast P-value $^{4}$} \\
\cline { 2 - 7 } Item & 70 & 85 & 100 & 115 & SEM $^{3}$ & $\mathrm{~L}$ & $\mathrm{Q}$ & $\mathrm{C}$ \\
\hline Intake, $\mathrm{kg} / \mathrm{d}$ & & & & & & & & \\
$\quad$ Forage DM & 2.00 & 2.00 & 1.99 & 1.99 & 0.02 & 0.67 & 0.89 & 0.73 \\
$\quad$ Concentrate & 2.70 & 3.41 & 4.12 & 4.84 & 0.08 & $<0.0$ & 0.97 & 0.92 \\
DM & & & & & & 1 & & \\
$\quad$ Total DM & 4.70 & 5.41 & 6.11 & 6.83 & 0.07 & $<0.0$ & 0.94 & 0.85 \\
& & & & & & 1 & & \\
ADF & 1.25 & 1.32 & 1.37 & 1.43 & 0.03 & $<0.0$ & 0.90 & 0.77 \\
& & & & & & 1 & & \\
Digestion, \% & & & & & & & & \\
DM & 62 & 62 & 62 & 63 & 2.0 & 0.80 & 0.71 & 0.80 \\
OM & 67 & 65 & 66 & 67 & 2.0 & 0.94 & 0.66 & 0.81 \\
ADF & 46 & 41 & 39 & 39 & 3.0 & 0.07 & 0.43 & 0.94 \\
GE & 63 & 62 & 63 & 64 & 2.0 & 0.65 & 0.63 & 0.87 \\
\hline
\end{tabular}

${ }^{1}$ Observed via feed and fecal nutrient analysis.

${ }^{2} 70=$ received $70 \%$ NRC requirements; $85=$ received $85 \%$ NRC requirements;

$100=$ received $100 \%$ NRC requirements; $115=$ received $115 \%$ NRC requirements.

${ }^{3} \mathrm{SEM}=$ standard error mean.

${ }^{4} \mathrm{~L}=$ Linear; $\mathrm{Q}=$ Quadratic; $\mathrm{C}=$ Cubic. 
Table 2.3. Apparent energy availability of treatment diets and estimates of retained energy ${ }^{1}$ and heat production ${ }^{2}$ in confined beef cows fed at four different levels of NRC predicted requirements for maintenance

\begin{tabular}{cccccccccc}
\hline & \multicolumn{4}{c}{ Treatment $^{3}$} & & & \multicolumn{3}{c}{ Contrast P-value $^{5}$} \\
\cline { 2 - 3 } Item & 70 & 85 & 100 & 115 & SEM $^{4}$ & $\mathrm{~L}$ & $\mathrm{Q}$ & $\mathrm{C}$ \\
\hline \multicolumn{2}{l}{ Energy } & Intake, & Mcal/d & & & & & & \\
$\mathrm{GE}$ & 9.41 & 10.91 & 12.35 & 13.86 & 0.27 & $<0.01$ & 0.95 & 0.86 \\
$\mathrm{DE}$ & 5.92 & 6.78 & 7.77 & 8.86 & 0.17 & $<0.01$ & 0.26 & 0.94 \\
& 4.85 & 5.56 & 6.37 & 7.26 & 0.14 & $<0.01$ & 0.26 & 0.94 \\
$\mathrm{ME}^{6}$ & & & & & & & & \\
$\mathrm{RE}$ & 0.90 & 0.97 & 2.04 & 2.38 & 0.34 & $<0.01$ & 0.67 & 0.23 \\
$\mathrm{HE}$ & 4.03 & 4.56 & 4.23 & 4.89 & 0.33 & 0.08 & 0.92 & 0.24 \\
\hline
\end{tabular}

${ }^{1} \mathrm{Mcal} / \mathrm{d}$, Calculated as RE/d.

${ }^{2} \mathrm{Mcal} / \mathrm{d}$, Calculated as (ME - RE)/d.

${ }^{3} 70=$ received $70 \%$ NRC requirements; $85=$ received $85 \%$ NRC requirements;

$100=$ received $100 \%$ NRC requirements; $115=$ received $115 \%$ NRC

requirements.

${ }^{4} \mathrm{SEM}=$ standard error mean.

${ }^{5} \mathrm{~L}=$ Linear; $\mathrm{Q}=$ Quadratic $; \mathrm{C}=$ Cubic

${ }^{6}$ Calculated as $\mathrm{DE} * .82$.

Percent of diet consumption (Table 2.4) significantly decreased with increasing diet provision $(P=0.03)$ and this difference, between the lowest and highest intakes, was $3.6 \%$ or approximately $0.21 \mathrm{~kg}$. Rate of consumption in $\mathrm{g} / \mathrm{min}$ was not significantly different $(P \geq 0.19)$ for the treatments; however, consumption time linearly increased as feed offered increased $(P<0.01)$. 
Table 2.4. As-fed consumption of treatment diets fed to confined beef cows at four different levels of NRC predicted requirements for maintenance ${ }^{1}$

\begin{tabular}{|c|c|c|c|c|c|c|c|c|}
\hline \multirow[b]{3}{*}{ Item } & \multicolumn{4}{|c|}{ Treatment $^{1}$} & \multirow[b]{3}{*}{$\begin{array}{l}\mathrm{SE} \\
\mathrm{M}^{2}\end{array}$} & \multicolumn{3}{|c|}{ Probability $(P=)^{3}$} \\
\hline & \multirow[t]{2}{*}{70} & \multirow[t]{2}{*}{85} & \multirow{2}{*}{100} & \multirow[t]{2}{*}{115} & & \multirow[t]{2}{*}{$\mathrm{L}$} & \multirow[t]{2}{*}{$\mathrm{Q}$} & \multirow[t]{2}{*}{$\mathrm{C}$} \\
\hline & & & & & & & & \\
\hline No. of observations & 15 & 14 & 12 & 14 & & & & \\
\hline Percent consumption & 98.4 & 98.6 & 98.0 & 94.8 & 1.19 & 0.03 & 0.16 & 0.76 \\
\hline Rate, $g / \min ^{4}$ & 75.8 & 69.8 & 66.6 & 72.9 & 5.67 & 0.55 & 0.19 & 0.74 \\
\hline $\begin{array}{l}\text { Consumption time, } \\
\min \end{array}$ & 75.6 & 85.3 & 93.3 & 98.2 & 2.35 & $\begin{array}{c}<0.0 \\
1\end{array}$ & 0.26 & 0.89 \\
\hline $\begin{array}{l}{ }^{1} 70=\text { received } 70 \% \\
100=\text { received } 100 \% \\
\text { requirements. } \\
{ }^{2} \mathrm{SEM}=\text { standard erro }\end{array}$ & C req & eme & $\begin{array}{l}; 85 \\
\text { tts; } 11\end{array}$ & & d 85\% & $\begin{array}{l}\text { NRC } \\
5 \% \mathrm{~N}\end{array}$ & equir & \\
\hline
\end{tabular}

Initial (d 0) BW did not differ across treatments $(P \geq 0.65)$, final (d 52) BW increased linearly $(P=0.05$; Table 2.5$)$, and BW gain linearly increased over the limitfeeding time period $(P<0.01$; Table 2.6$)$ from $0.7 \mathrm{~kg}$ for $70 \%$ to $3.6,17.7$, and $24.2 \mathrm{~kg}$ for 85,100 , and $115 \%$. Body condition scores did not differ across treatments on d 0 ( $P$ $\geq 0.16)$, but by $\mathrm{d} 52$ they significantly increased $(P=0.02)$ with increased feed offered. Cow BW remained greater (linear, $P \leq 0.04$ ) in cows offered increasing levels of energy at days 60 and 90 post parturition; and tended $(P=0.09)$ to increase at d 120, however, treatments no longer differed $(P \geq 0.33)$ at 160 days post parturition or at weaning $(\mathrm{d} 270$ post parturition). Cow BCS tended $(P=0.07)$ to remain linearly greater at $120 \mathrm{~d}$ postparturition but these differences were not apparent at $160 \mathrm{~d}$ post-parturition or at weaning $(P \geq 0.12)$.

Ultrasound measurements (Table 2.6) for rib fat, measured prior to the application of treatment increased linearly $(P=0.03)$ from $6.35 \mathrm{~mm}$ for $70 \%$ to 6.35 , 
8.09 , and 8.25 for 85,100 and $115 \%$. Rib fat measurements at the termination of the 52 d period tended to increase linearly $(P=0.09)$; however, change in rib fat was not significantly affected $(P \geq 0.70)$ by level of intake. There were no significant differences $(P \geq 0.13)$ between treatments for initial, final or change in rump fat or intramuscular fat. No differences $(P \geq 0.25)$ in ultrasound measurements for Ribeye area (REA) at d 0 were detected. However, REA at d 52 tended $(P=0.09)$ to increase linearly and change in REA ( 0 to $\mathrm{d} 52)$ increased $(P=0.05)$ with increasing energy offered.

Cow daily RE estimates (Table 2.3) calculated using the NRC (2000), Herd and Sprott (1988) and Ferrell et al., (1976a), during the limit-feeding period (d 0 to 52) increased linearly $(P<0.01)$ from $0.90 \mathrm{Mcal} / \mathrm{d}$ for $70 \%$ to $0.97,2.04$, and $2.38 \mathrm{Mcal}$ for 85, 100, and 115\%. Calculated heat energy (HE), estimated using NRC (2000) equations, tended to increase linearly $(P=0.08)$ in response to increased energy consumption. 
Table 2.5. Calving and post calving body weight and condition score ${ }^{4}$ measurements of confined beef cows fed at four different levels of NRC predicted requirements for maintenance

\begin{tabular}{|c|c|c|c|c|c|c|c|c|}
\hline \multirow[b]{2}{*}{ Item } & \multicolumn{4}{|c|}{ Treatment $^{1}$} & \multirow[b]{2}{*}{$\mathrm{SEM}^{2}$} & \multicolumn{3}{|c|}{ Probability $(P=)^{3}$} \\
\hline & 70 & 85 & 100 & 115 & & $\mathrm{~L}$ & $\mathrm{Q}$ & $\mathrm{C}$ \\
\hline \multicolumn{9}{|l|}{$\begin{array}{l}\text { Body weight, } \\
\text { kg }\end{array}$} \\
\hline$-26 d$ & 525 & 529 & 523 & 526 & 18.94 & 0.94 & 0.91 & 0.66 \\
\hline$-10 d$ & 492 & 491 & 487 & 488 & 15.93 & 0.70 & 0.96 & 0.88 \\
\hline $0 \mathrm{~d}$ & 473 & 476 & 472 & 480 & 15.61 & 0.67 & 0.78 & 0.65 \\
\hline $22 \mathrm{~d}$ & 489 & 490 & 497 & 500 & 15.90 & 0.34 & 0.91 & 0.78 \\
\hline $52 \mathrm{~d}$ & 507 & 502 & 523 & 532 & 18.51 & 0.05 & 0.48 & 0.50 \\
\hline Calving & 469 & 476 & 489 & 510 & 17.61 & $<0.01$ & 0.49 & 0.96 \\
\hline \multicolumn{9}{|l|}{ Post Calving } \\
\hline $60 \mathrm{~d}$ & 469 & 471 & 491 & 504 & 16.78 & $<0.01$ & 0.58 & 0.61 \\
\hline $90 \mathrm{~d}$ & 473 & 488 & 492 & 498 & 15.97 & 0.04 & 0.63 & 0.78 \\
\hline $120 \mathrm{~d}$ & 492 & 504 & 509 & 515 & 16.61 & 0.09 & 0.81 & 0.86 \\
\hline $160 \mathrm{~d}$ & 505 & 514 & 513 & 519 & 16.31 & 0.33 & 0.85 & 0.73 \\
\hline Weaning & 479 & 489 & 486 & 493 & 16.05 & 0.36 & 0.93 & 0.59 \\
\hline \multicolumn{9}{|l|}{$(200 d)$} \\
\hline \multicolumn{9}{|l|}{$\mathrm{BCS}^{4}$} \\
\hline$-26 d$ & 5.87 & 5.87 & 5.86 & 5.73 & 0.10 & 0.36 & 0.54 & 0.82 \\
\hline$-10 d$ & 5.33 & 5.26 & 5.23 & 5.26 & 0.13 & 0.57 & 0.59 & 0.93 \\
\hline $0 \mathrm{~d}$ & 5.13 & 5.33 & 5.26 & 5.40 & 0.13 & 0.16 & 0.78 & 0.37 \\
\hline $22 \mathrm{~d}$ & 5.42 & 5.41 & 5.51 & 5.52 & 0.14 & 0.44 & 0.95 & 0.68 \\
\hline $52 \mathrm{~d}$ & 5.41 & 5.48 & 6.00 & 5.79 & 0.21 & 0.02 & 0.40 & 0.12 \\
\hline Calving & 5.12 & 5.32 & 5.87 & 5.77 & 0.19 & $<0.01$ & 0.39 & 0.20 \\
\hline \multicolumn{9}{|l|}{ Post Calving } \\
\hline $60 \mathrm{~d}$ & 4.85 & 4.91 & 5.40 & 5.19 & 0.15 & $<0.01$ & 0.26 & 0.05 \\
\hline $120 \mathrm{~d}$ & 5.88 & 6.04 & 6.42 & 6.13 & 0.19 & 0.07 & 0.12 & 0.18 \\
\hline $160 \mathrm{~d}$ & 5.70 & 5.98 & 6.09 & 6.01 & 0.17 & 0.12 & 0.22 & 0.96 \\
\hline $\begin{array}{l}\text { Weaning } \\
(200 \mathrm{~d})\end{array}$ & 5.28 & 5.16 & 5.42 & 5.15 & 0.16 & 0.85 & 0.57 & 0.17 \\
\hline $\begin{array}{l}{ }^{1} 70=\text { received } \\
\text { requirements; } \\
100=\text { receivec } \\
\text { requirements. } \\
{ }^{2} \mathrm{SEM}=\text { stand } \\
{ }^{3} \mathrm{~L}=\text { Linear; } \\
{ }^{4} \mathrm{BCS} \text { of } 1=\mathrm{e}\end{array}$ & $\begin{array}{l}\% \mathrm{NR} \\
0 \% \mathrm{NI}\end{array}$ & $\begin{array}{l}\text { requir } \\
\mathrm{C} \text { requ }\end{array}$ & $\begin{array}{l}\text { ments } \\
\text { remen }\end{array}$ & $\begin{array}{l}85=r \\
; 115\end{array}$ & $\begin{array}{l}\text { ceived } 8 \\
\text { receive }\end{array}$ & $\begin{array}{l}\% \mathrm{NRC} \\
115 \% \mathrm{~N}\end{array}$ & & \\
\hline
\end{tabular}


Table 2.6. Initial and final body weight and ultrasound measurements, over a $52 \mathrm{~d}$ limit-feeding period, of confined beef cows fed at four different levels of NRC predicted requirements for maintenance

\begin{tabular}{|c|c|c|c|c|c|c|c|c|}
\hline \multirow[b]{2}{*}{ Item } & \multicolumn{4}{|c|}{ Treatment $^{1}$} & \multirow[b]{2}{*}{ SEM $^{2}$} & \multicolumn{3}{|c|}{ Probability $(P=)^{3}$} \\
\hline & 70 & 85 & 100 & 115 & & $\mathrm{~L}$ & $\mathrm{Q}$ & $\mathrm{C}$ \\
\hline \multicolumn{9}{|l|}{$\begin{array}{l}\text { Initial } \\
\text { measurements }\end{array}$} \\
\hline EBW, kg & 165 & 164 & 457 & 160 & 15.52 & 0.59 & 0.81 & 0.67 \\
\hline $\mathrm{EBW}^{0.75}, \mathrm{~kg}$ & 97 & 97 & 96 & 98 & 2.53 & 0.79 & 0.62 & 0.41 \\
\hline Hip fat, mm & 7.75 & 8.50 & 9.03 & 9.38 & 1.08 & 0.19 & 0.83 & 0.99 \\
\hline Rib fat, mm & 6.00 & 6.35 & 8.09 & 8.25 & 0.97 & 0.03 & 0.91 & 0.44 \\
\hline $\begin{array}{l}\text { Ribeye area, } \\
\mathrm{cm}^{2}\end{array}$ & 68.19 & 70.13 & 70.74 & 71.39 & 2.26 & 0.25 & 0.75 & 0.89 \\
\hline $\begin{array}{l}\text { Intramuscular } \\
\text { fat, } \%\end{array}$ & 3.84 & 3.70 & 3.81 & 3.69 & 0.25 & 0.73 & 0.93 & 0.63 \\
\hline \multicolumn{9}{|l|}{$\begin{array}{l}\text { Final } \\
\text { measurements }\end{array}$} \\
\hline EBW, kg & 176 & .65 & 477 & 84 & 19.49 & 0.47 & 0.45 & 0.65 \\
\hline $\mathrm{EBW}^{0.75}, \mathrm{~kg}$ & 98 & 97 & 100 & 02 & 3.06 & 0.11 & 0.39 & 0.65 \\
\hline Hip fat, mm & 7.03 & 7.65 & 9.44 & 8.87 & 1.27 & 0.13 & 0.59 & 1.49 \\
\hline Rib fat, mm & 5.99 & 5.97 & 7.65 & 8.02 & 1.23 & 0.09 & 0.85 & 0.53 \\
\hline $\begin{array}{l}\text { Ribeye area, } \\
\mathrm{cm}^{2}\end{array}$ & 60.42 & 68.13 & 68.96 & 76.18 & 4.48 & $<0.01$ & 0.95 & 0.45 \\
\hline $\begin{array}{l}\text { Intramuscular } \\
\text { fat, } \%\end{array}$ & 3.78 & 3.63 & 3.49 & 3.56 & 0.27 & 0.44 & 0.36 & 0.86 \\
\hline \multicolumn{9}{|c|}{$\begin{array}{c}\text { Change in } \\
\text { measurements }\end{array}$} \\
\hline $\mathrm{EBW}, \mathrm{kg}$ & 0.7 & 3.6 & 17.7 & 24.2 & 4.64 & $<0.01$ & 0.66 & 0.33 \\
\hline $\mathrm{EBW}^{0.75}, \mathrm{~kg}$ & 0.1 & 0.6 & 2.9 & 3.9 & 0.75 & $<0.01$ & 0.68 & 0.31 \\
\hline Hip fat, mm & -0.91 & -1.03 & 0.23 & -0.78 & 0.81 & 0.58 & 0.52 & 0.26 \\
\hline Rib fat, mm & -0.29 & -0.37 & -0.20 & -0.20 & 0.30 & 0.70 & 0.88 & 0.75 \\
\hline $\begin{array}{l}\text { Ribeye area, } \\
\mathrm{cm}^{2}\end{array}$ & -7.64 & -1.71 & -0.82 & 5.35 & 4.36 & 0.02 & 0.96 & 0.56 \\
\hline $\begin{array}{l}\text { Intramuscular } \\
\text { fat, } \%\end{array}$ & -0.29 & -0.06 & -0.26 & -0.09 & 0.17 & 0.52 & 0.85 & 0.23 \\
\hline $\begin{array}{l}{ }^{1} 70=\text { received } 7 \\
100=\text { received } 1 \\
\text { requirements. } \\
{ }^{2} \mathrm{SEM}=\text { standar } \\
{ }^{3} \mathrm{~L}=\text { Linear; } \mathrm{Q}=\end{array}$ & $\begin{array}{l}\% \text { NRC } \\
0 \% \mathrm{NR} \\
\text { error } \mathrm{m}\end{array}$ & $\begin{array}{l}\text { require } \\
\text { C requi }\end{array}$ & $\begin{array}{l}\text { ments; } 8 \\
\text { rements; }\end{array}$ & $\begin{array}{l}5=\text { rec } \\
115=\end{array}$ & $\begin{array}{l}\text { ved } 85 \% \\
\text { ceived } 1\end{array}$ & $\begin{array}{l}6 \mathrm{NRC} \\
15 \% \mathrm{~N}\end{array}$ & $\begin{array}{l}\text { quire } \\
\text { C }\end{array}$ & \\
\hline
\end{tabular}


Calving date was not significantly affected $(P<0.05)$ by energy intake.

However, calf birth weight (Table 2.7) increased linearly $(P=0.01)$ from $32.5 \mathrm{~kg}$ for $70 \%$ to $35.5,35.2$, and $36.8 \mathrm{~kg}$ for 85,100 , and $115 \%$. However, level of energy offered during gestation did not result in significant differences $(P \geq 0.24)$ in calf weights at 60 , 90, 120 or 160 days post parturition or at weaning (averaged $206 \mathrm{~kg}$ ). Cow 30 and $60 \mathrm{~d}$ conception rates were $82 \%$ and $98 \%$, respectively. Post-partum interval and subsequent calf birth weights were not significantly different $(P>0.05)$.

Brix $(\%)$ values for colostrum (Table 2.8$)$ at parturition did not differ $(P=0.14)$ as a result of dietary treatment and at $24 \mathrm{~h}$ post parturition showed a cubic response $(P=$ 0.03). Immunoglobulin G levels (Table 2.9) in calf serum collected at birth, $24 \mathrm{~h}$ and $7 \mathrm{~d}$ did not differ $(P \geq 0.15)$ and averaged 47, 4,749, and 4,464 mg/dL, respectively. 
Table 2.7. Body weight measurements of progeny from beef cows fed in confinement at four different levels of NRC predicted requirements for maintenance after returning to a common herd ${ }^{1}$

\begin{tabular}{|c|c|c|c|c|c|c|c|c|}
\hline \multirow[b]{2}{*}{ Item } & \multicolumn{4}{|c|}{ Treatment $^{1}$} & \multicolumn{4}{|c|}{ Probability $(P=)^{3}$} \\
\hline & 70 & 85 & 100 & 115 & SEM & $\mathrm{L}$ & $\mathrm{Q}$ & $\mathrm{C}$ \\
\hline \multicolumn{9}{|l|}{ Calf BW, kg } \\
\hline Birth & 32 & 35 & 35 & 37 & 1.20 & 0.01 & 0.54 & 0.34 \\
\hline $60 \mathrm{~d}$ & 85 & 87 & 92 & 90 & 5.68 & 0.37 & 0.67 & 0.70 \\
\hline $90 \mathrm{~d}$ & 107 & 105 & 116 & 114 & 6.98 & 0.26 & 0.97 & 0.41 \\
\hline $120 \mathrm{~d}$ & 144 & 151 & 154 & 150 & 6.02 & 0.42 & 0.36 & 0.89 \\
\hline $160 \mathrm{~d}$ & 177 & 180 & 184 & 181 & 6.33 & 0.49 & 0.67 & 0.80 \\
\hline Weaning weight & 199 & 205 & 217 & 204 & 8.47 & 0.41 & 0.24 & 0.39 \\
\hline
\end{tabular}

${ }^{1}$ Cows were returned to a common heard $24 \mathrm{~h}$ post parturition.

${ }^{2} 70=$ received $70 \%$ NRC requirements; $85=$ received $85 \%$ NRC requirements;

$100=$ received $100 \%$ NRC requirements; $115=$ received $115 \%$ NRC requirements.

${ }^{2} \mathrm{SEM}=$ standard error mean.

${ }^{3} \mathrm{~L}=$ Linear; $\mathrm{Q}=$ Quadratic; $\mathrm{C}=$ Cubic.

Table 2.8. Colostrum measurements of beef cows fed in confinement at four different levels of NRC predicted requirements for maintenance

\begin{tabular}{|c|c|c|c|c|c|c|c|c|}
\hline \multirow[b]{2}{*}{ Item } & \multicolumn{4}{|c|}{ Treatment $^{1}$} & \multirow[b]{2}{*}{$\mathrm{SEM}^{2}$} & \multicolumn{3}{|c|}{ Probability $(P=)^{3}$} \\
\hline & 70 & 85 & 100 & 115 & & $\mathrm{~L}$ & $\mathrm{Q}$ & $\mathrm{C}$ \\
\hline \multicolumn{9}{|l|}{ Brix, \% } \\
\hline At parturition & 27.41 & 27.77 & 25.99 & 24.72 & 1.57 & 0.14 & 0.59 & 0.71 \\
\hline $24 \mathrm{~h}$ post-parturition & 13.61 & 10.93 & 14.18 & 12.39 & 1.16 & 0.93 & 0.67 & 0.03 \\
\hline Colostrum somatic cell count ${ }^{4}$ & 1365.00 & 2626.67 & 1670.29 & 521.78 & 1099.46 & 0.41 & 0.24 & 0.67 \\
\hline
\end{tabular}

${ }^{1} 70=$ received $70 \%$ NRC requirements; $85=$ received $85 \%$ NRC requirements;

$100=$ received $100 \%$ NRC requirements; $115=$ received $115 \%$ NRC requirements.

${ }^{2} \mathrm{SEM}=$ standard error mean.

${ }^{3} \mathrm{~L}=$ Linear; $\mathrm{Q}=$ Quadratic; $\mathrm{C}=$ Cubic.

${ }^{4}$ Collected $24 \mathrm{~h}$ post parturition. 
Table 2.9. Serum immunoglobulin $G$ measurements of progeny from beef cows fed in confinement at four different levels of NRC predicted requirements for maintenance

\begin{tabular}{|c|c|c|c|c|c|c|c|c|}
\hline \multirow[b]{2}{*}{ Item } & \multicolumn{4}{|c|}{ Treatment $^{1}$} & \multicolumn{4}{|c|}{ Probability $(P=)^{3}$} \\
\hline & 70 & 85 & 100 & 115 & $\mathrm{SEM}^{2}$ & $\mathrm{~L}$ & $\mathrm{Q}$ & $\mathrm{C}$ \\
\hline \multicolumn{9}{|c|}{ Serum Immunoglobulin $\mathrm{G}, \mathrm{mg} / \mathrm{dL}$} \\
\hline At birth & 55 & 68 & 32 & 34 & 39 & 0.56 & 0.88 & 0.60 \\
\hline $24 \mathrm{~h}$ post-birth & 4822 & 4679 & 4612 & 4886 & 208 & 0.87 & 0.21 & 0.72 \\
\hline One week post-birth ${ }^{4}$ & 4650 & 4745 & 4164 & 4300 & 257 & 0.15 & 0.94 & 0.23 \\
\hline
\end{tabular}

${ }^{1} 70=$ received $70 \%$ NRC requirements; $85=$ received $85 \%$ NRC requirements;

$100=$ received $100 \%$ NRC requirements; $115=$ received $115 \%$ NRC requirements.

${ }^{2} \mathrm{SEM}=$ standard error mean.

${ }^{3} \mathrm{~L}=$ Linear; $\mathrm{Q}=$ Quadratic; $\mathrm{C}=$ Cubic.

${ }^{4}$ Cows were returned to a common heard $24 \mathrm{~h}$ post parturition. 


\section{Discussion}

The objective of this study was to quantify the effects of dietary energy intake on nutrient utilization, performance, and maintenance requirements in late gestation cows and their calves.

Reduced intake is associated with slower passage of digesta (Colucci et al., 1990) which is known to increase the digestion of feed (Tyrrell and Moe, 1975). Reducing DM intake across treatments in this study did not result in increased DM or OM digestion, unlike what has been observed in similar studies (Galyean et al., 1979, Trubenbach 2014, Boardman 2015).

As intake increased across treatments, so did the concentrate to forage ratio of the diets - since concentrate is more rapidly digested (Colucci et al., 1982) this may have countered the slower passage rate and associated higher digestion expected in the lower DMI treatments. High-concentrate diets have been associated with increased activity of ruminal amylolytic bacteria (Mackie et al., 1979). Activity of amylolytic bacteria in this study, particularly in the rumen of cows fed diets with greater proportions of concentrate might have outcompeted the cellulolytic bacteria, helping to explain the significant decrease in ADF digestion observed as intake increased. Additionally, the significant increase in ADF intake may explain the significant decrease in ADF digestion across treatments. Acid detergent fiber digestion is inversely related to DM digestion (Erdman et al., 1986), which may further explain the absence of a greater DM digestion in the low intake treatments. 
Retained energy was predicted using regression equations (NRC, 2000; Ferrell et al., 1976a and Herd and Sprott, 1988), and as expected and similarly demonstrated by Trubenbach (201X), it significantly increased with increasing levels of MEI. Though RE was above zero for all treatments this may be attributed to the extensive growth of the conceptus and gravid uterus during the third trimester (Quigley III and Drewry, 1998; Reynolds et al., 1986; Tyrell, 1972). Reduced intake resulted in decreased heat production in multiple studies (Freetly and Nienaber, 1998; Freetly et al., 2006, Trubenbach, 2014; Boardman, 2015), in this study comparing cows fed at $70 \%$ to those fed at $115 \%$ resulted in an estimated reduction in daily $\mathrm{HE}$ of $17 \%$.

Dam body weight and BCS score at parturition is often cited for its impact on post-partum interval (Wiltbank et al., 1962; Bellows and Short, 1978; Dunn and Kaltenbach, 1980; Bellows et al., 1982). Body weight and BCS scores increased linearly with increased nutrient provision on d 52 of the trial. However, these differences were no longer significant in cows by $120 \mathrm{~d}$ post parturition, suggesting that cows were able to overcome previous intake restriction. Additionally, cow 30 and $60 \mathrm{~d}$ conception rates were $82 \%$ and $98 \%$, respectively and post-partum interval did not significantly differ.

In concurrence with data (Wiltbank et al., 1962; Tudor, 1972; Hough et al., 1990) feed restricting dams during late pregnancy resulted in significantly lower calf birth weights. However there were no significant differences in calf weights by $60 \mathrm{~d}$ post parturition similar to findings from Freetly et al., (2000). Calf weight data in this study suggests that limit-feeding cows during their third trimester of gestation may be a strategy to reduce calf birth-weight associated dystocia without ensuing deleterious 
effects on calf weaning weights. Reduced intake of third trimester cows did not negatively affect passive immune transfer as calf serum $\operatorname{IgG}$ levels did not differ at birth (pre-nursing), $24 \mathrm{~h}$ post-birth or $7 \mathrm{~d}$ post-birth. Additionally, calf mortality measured until weaning did not differ across treatments. Successful passive immune transfer was expected as no significant differences in dam's colostrum Brix \%, an indicator of colostrum IgG levels, or colostrum somatic cell counts were observed in this study. Though total colostrum volume was not measured, intake restriction did not appear to effect colostrum quality or subsequent passive immune transfer from dam to calf.

Feed restricting cows during late-gestation to $70 \%$ of their NRC predicted maintenance energy requirements did not result in deleterious effects on calf growth or subsequent reproductive success of the dam. However, an economic assessment of this feeding strategy should be considered in order to determine its efficacy in a production system. In terms of diet delivery, data from Baber et al. (2016) showed that limit-fed, high-concentrate diets can be parsed into hay and concentrate portions fed separately without compromising cow performance, eliminating costs associated with mixing a TMR. In terms of diet depletion, rate of consumption, in $\mathrm{g} / \mathrm{min}$ did not differ across treatments in this study. However, use of the Calan gate feeding system may have eliminated intake differences associated with differences in cow eating behaviors. 


\section{CHAPTER III}

\section{SUMMARY}

Results from this study successfully demonstrated the effects of offering decreasing levels of energy to third-trimester cows. Cows offered $70 \%$ of their NRCpredicted maintenance energy requirements remained in a positive energy balance throughout the limit-feeding portion of this study, averaged total pounds of calf weaned similar to cows offered energy at and above their NRC-predicted requirements, and remained reproductively sound through the following calving season.

It is possible that these results were obtained because cows adapted their maintenance energy requirements in response to their treatment scenarios. It is also possible that results were observed because the NRC over predicted the maintenance energy requirements of cows in this study. Additionally, a combination of both of these circumstances is also possible. In any case, the results of this study indicate the viability of limit-feeding, high-concentrate diets to third trimester cows in confinement as an option for beef producers. Future research, illuminating the effects of limit-feeding, high-concentrate diets to cows through their calving and subsequent production cycles would be meaningful to this area of study. 


\section{REFERENCES}

Alexandratos, N., and J. Bruinsma. 2012. World agriculture towards 2030/2050: the 2012 revision. ESA Working paper Rome, FAO.

Allen, M. S. 1997. Relationship between fermentation acid production in the rumen and the requirement for physically effective fiber. J. Dairy Sci. 80:1447-1462.

Anderson, R. R., and T. R. Bauman. 1968. Thyroid hormone secretion rates of cows in dry period and during lactation. In: J. Dair. Sci. V. 51. Amer. dairy science assoc. Savor, IL 61874. p. 955-.

Araujo, R. L., B. M. Andrade, A. S. Padrón, M. P. Gaidhu, R. L. S. Perry, D. P. Carvalho, and R. B. Ceddia. 2010. High-fat diet increases thyrotropin and oxygen consumption without altering circulating 3, 5, 3'-triiodothyronine (T3) and thyroxine in rats: the role of iodothyronine deiodinases, reverse T3 production, and whole-body fat oxidation. Endocrinology. 151:3460-3469.

Baber, J. R. 2016. Evaluating feasibility of alternative feeding methods for limit-fed cow-calf systems. Master's thesis. Texas A\&M Univ., College Station.

Barker, D. J., K. M. Godfrey, P. D. Gluckman, J. E. Harding, J. A. Owens, and J. S. Robinson. 1993. Fetal nutrition and cardiovascular disease in adult life. The Lancet. 341:938-941. 
Barrington, G. M., T. B. McFadden, M. T. Huyler, and T. E. Besser. 2001. Regulation of colostrogenesis in cattle. Livest. Prod. Sci. 70:95-104. doi:10.1016/S03016226(01)00201-9.

Bellows, R. A., and R. E. Short. 1978. Effects of precalving feed level on birth weight, calving difficulty and subsequent fertility. J. Anim. Sci. 46:1522-1528.

Bellows, R. A., R. E. Short, and G. V. Richardson. 1982. Effects of sire, age of dam and gestation feed level on dystocia and postpartum reproduction. J. Anim. Sci. 55:1827.

Bielmann, V., J. Gillan, N. R. Perkins, A. L. Skidmore, S. Godden, and K. E. Leslie. 2010. An evaluation of Brix refractometry instruments for measurement of colostrum quality in dairy cattle. J. Dairy Sci. 93:3713-3721. doi:10.3168/jds.2009-2943.

Boardman, C. J. 2015. Effects of monensin and dietary energy intake on maintenance requirements in beef cows. Master's thesis. Texas A\&M Univ., College Station.

Bradford, G. E. 1999. Contributions of animal agriculture to meeting global human food demand. Livest. Prod. Sci. 59:95-112. doi:10.1016/S0301-6226(99)00019-6.

Brody, S. 1945. Bioenergetics and growth. Rheinhold Pub. Co., New York.

Burrin, D. G., R. A. Britton, and C. L. Ferrell. 1988. Visceral organ size and hepatocyte metabolic activity in fed and fasted rats. J. Nutr. 118:1547-1552. 
Burrin, D. G., C. L. Ferrell, R. A. Britton, and M. Bauer. 1990. Level of nutrition and visceral organ size and metabolic activity in sheep. Br. J. Nutr. 64:439-448. doi:10.1079/BJN19900044.

Butler. 2014. Look how much bigger thanksgiving turkeys are today than in the 1930s. http://www.motherjones.com/environment/2014/11/turkey-bigger-thanksgivingbutterball-antibiotics/(Accesses 8 August 2017.

Canas, R., J. J. Romero, and R. L. Baldwin. 1982. Maintenance energy requirements during lactation in rats. J. Nutr. 112:1876-1880.

Cattlemen's Beef Board and National Cattlemen's Beef Association. 2014. Executive summary. Colorado, Centennial.

Chucri, T. M., J. M. Monteiro, A. R. Lima, M. L. B. Salvadori, J. R. K. Junior, and M. A. Miglino. 2010. A review of immune transfer by the placenta. J. Reprod. Immunol. 87:14-20. doi:10.1016/j.jri.2010.08.062.

Collier, P. 2002. The macroeconomic repercussions of agricultural shocks and their implications for insurance. WIDER Discussion Papers//World Institute for Development Economics (UNU-WIDER).

Colucci, P. E., L. E. Chase, and P. J. Van Soest. 1982. Feed Intake, Apparent Diet Digestibility, and Rate of Particulate Passage in Dairy Cattle. J. Dairy Sci. 65:14451456. doi:10.3168/jds.S0022-0302(82)82367-9. 
Colucci, P. E., G. K. Macleod, W. L. Grovum, I. McMillan, and D. J. Barney. 1990. Digesta Kinetics in Sheep and Cattle Fed Diets with Different Forage to Concentrate Ratios at High and Low Intakes. J. Dairy Sci. 73:2143-2156. doi:10.3168/jds.S00220302(90)78895-9.

Corah, L. R., T. G. Dunn, and C. C. Kaltenbach. 1975. Influence of prepartum nutrition on the reproductive performance of beef females and the performance of their progeny. J. Anim. Sci. 41:819-824.

Danforth, E., and A. Burger. 1984. The role of thyroid hormones in the control of energy expenditure. Clin. Endocrinol. Metab. 13:581-595. doi:10.1016/S0300$595 X(84) 80039-0$.

Deelen, S. M., T. L. Ollivett, D. M. Haines, and K. E. Leslie. 2014. Evaluation of a Brix refractometer to estimate serum immunoglobulin $\mathrm{G}$ concentration in neonatal dairy calves. J. Dairy Sci. 97:3838-3844. doi:10.3168/jds.2014-7939.

Delgado, C. L., C. Courbois, and M. W. Rosegrant. 1998. Global food demand and the contribution of livestock as we enter the new millennium. International Food Policy Research Institute (IFPRI).

De Vries, M., and I. J. M. de Boer. 2010. Comparing environmental impacts for livestock products: A review of life cycle assessments. Livest. Sci. 128:1-11. doi:10.1016/j.livsci.2009.11.007. 
Dunn, T. G., and C. C. Kaltenbach. 1980. Nutrition and the postpartum interval of the ewe, sow and cow. J. Anim. Sci. 51:29-39.

Effects of diet forage:concentrate ratio and metabolizable energy intake on visceral organ growth and in vitro oxidative capacity of gut tissues in sheep - 760. Available from: https://www.animalsciencepublications.org/publications/jas/pdfs/78/3/760

Eley, R. M., W. W. Thatcher, F. W. Bazer, C. J. Wilcox, R. B. Becker, H. H. Head, and R. W. Adkinson. 1978. Development of the Conceptus in the Bovine1. J. Dairy Sci. 61:467-473.

Enerdata. 2013. The state of global energy efficiency, global and sectorial energy efficiency trends. ABB Ltd. Zurich, Switzerland.

Eom, S., and E. Kim. 2006. A survey of decision support system applications (19952001). J. Oper. Res. Soc. 57:1264-1278. doi:10.1057/palgrave.jors.2602140.

FAOSTAT. 2016. (Food and Agriculture Organization of the United Nations, FAOSTAT database). http://www.fao.org/faostat/en/\#data/BL (Accessed August 2016.)

Ferrell, C. L. 1988. Contribution of visceral organs to animal energy expenditures. J. Anim. Sci. 66:23-34.

Ferrell, C. L., W. N. Garrett, and N. Hinman. 1976. Growth, development and composition of the udder and gravid uterus of beef heifers during pregnancy. $\mathrm{J}$. Anim. Sci. 42:1477-1489. 
Ferrell, C. L., L. J. Koong, and J. A. Nienaber. 1986. Effect of previous nutrition on body composition and maintenance energy costs of growing lambs. Br. J. Nutr. 56:595-605. doi:10.1079/BJN19860140.

Fleenor, W. A., and G. H. Stott. 1980. Hydrometer Test for Estimation of Immunoglobulin Concentration in Bovine Colostrum1. J. Dairy Sci. 63:973-977.

Freetly, H. C., C. L. Ferrell, and T. G. Jenkins. 2000. Timing of realimentation of mature cows that were feed-restricted during pregnancy influences calf birth weights and growth rates. J. Anim. Sci. 78:2790-6.

Freetly, H. C., and J. A. Nienaber. 1998. Efficiency of energy and nitrogen loss and gain in mature cows. J. Anim. Sci. 76:896-905.

Freetly, H. C., J. A. Nienaber, and T. Brown-Brandl. 2006. Changes in heat production by mature cows after changes in feeding level. J. Anim. Sci. 84:1429-1438.

Freetly, H. C., J. A. Nienaber, and T. Brown-Brandl. 2008. Partitioning of energy in pregnant beef cows during nutritionally induced body weight fluctuation. J. Anim. Sci. 86:370-377.

Galyean, M. L., D. G. Wagner, and F. N. Owens. 1979. Level of feed intake and site and extent of digestion of high concentrate diets by steers. J. Anim. Sci. 49:199-203. 
Godfray, H. C. J., J. R. Beddington, I. R. Crute, L. Haddad, D. Lawrence, J. F. Muir, J. Pretty, S. Robinson, S. M. Thomas, and C. Toulmin. 2010. Food security: the challenge of feeding 9 billion people. science. 327:812-818.

Godfrey, K. M., and D. J. Barker. 2000. Fetal nutrition and adult disease. Am. J. Clin. Nutr. 71:1344s-1352s.

Godfrey, K., S. Robinson, D. J. P. Barker, C. Osmond, and V. Cox. 1996. Maternal nutrition in early and late pregnancy in relation to placental and fetal growth. Bmj. $312: 410$.

Hall, C. A., S. Balogh, and D. J. Murphy. 2009. What is the minimum EROI that a sustainable society must have? Energies. 2:25-47.

Hansen, J., and F. Gale. 2014. China in the Next Decade: Rising Meat Demand and Growing Imports of Feed. Amber Waves. 1A,2A,3A,4A,5A,6A,7A,8A,9A,10A.

Herd, D. B., and L. R. Sprott. 1986. Body condition, nutrition and reproduction of beef cows. Tex. FARMER Collect.

Hough, R. L., F. D. McCarthy, H. D. Kent, D. E. Eversole, and M. L. Wahlberg. 1990. Influence of nutritional restriction during late gestation on production measures and passive immunity in beef cattle. J. Anim. Sci. 68:2622-2627.

Huntington, G. B. 1990. Energy metabolism in the digestive tract and liver of cattle: influence of physiological state and nutrition. Reprod. Nutr. Dev. 30:35-47. 
Johnson, D. E., K. A. Johnson, and R. L. Baldwin. 1990. Changes in liver and gastrointestinal tract energy demands in response to physiological workload in ruminants. J. Nutr. 120:649-655.

Kester, W. 2003. Bigger and fewer. http://www.beefmagazine.com/mag/beef_bigger_fewer (Accessed 26 October 2017).

Lofgreen, G. P., and W. N. Garrett. 1968. A system for expressing net energy requirements and feed values for growing and finishing beef cattle. J. Anim. Sci. 27:793-806.

Look How Much Bigger Thanksgiving Turkeys Are Today Than in the 1930s - Mother Jones. Available from: http://www.motherjones.com/environment/2014/11/turkeybigger-thanksgiving-butterball-antibiotics/

McBride, B. W., and J. M. Kelly. 1990. Energy cost of absorption and metabolism in the ruminant gastrointestinal tract and liver: a review. J. Anim. Sci. 68:2997-3010.

McCartney, M. G., K. E. Nestor, and W. R. Harvey. 1968. Genetics of growth and reproduction in the turkey: 2 . Selection for increased body weight and egg production. Poult. Sci. 47:981-990.

Miller, A. J., D. B. Faulkner, R. K. Knipe, D. R. Strohbehn, and et al. 2001. Critical control points for profitability in the cow-calf enterprise. Prof. Anim. Sci. Champaign. 17:295. 
Miller, K. 2012. 2012 CattleFax Outlook.

http://www.angusjournal.com/ArticlePDF/NCBACattleFax\%203_12\%20AJ.pdf (Accessed 26 October 2017).

Moe, P. W., and H. F. Tyrrell. 1972. Metabolizable energy requirements of pregnant dairy cows. J. Dairy Sci. 55:480-483.

NASA. 2007. Drought in the Southeast.

https://earthobservatory.nasa.gov/NaturalHazards/view.php?id=8036\&eocn=image \& eoci=morenh (Accessed 26 October 2017).

Naylor, J. M., and D. S. Kronfeld. 1977. Refractometry as a measure of the immunoglobulin status of the newborn dairy calf: comparison with the zinc sulfate turbidity test and single radial immunodiffusion. Am. J. Vet. Res. 38:1331-1334.

NRC. 2000. Nutrient requirements of beef cattle. 7th rev. ed. Natl. Acad. Press, Washington, DC.

Oltjen, J. W., and J. L. Beckett. 1996. Role of ruminant livestock in sustainable agricultural systems. J. Anim. Sci. 74:1406-1409.

Pácha, J. 2000. Development of Intestinal Transport Function in Mammals. Physiol. Rev. 80:1633-1667.

Panu, U. S., and T. C. Sharma. 2002. Challenges in drought research: some perspectives and future directions. Hydrol. Sci. J. 47:S19-S30. 
Paterson, John. 2014. Where can we support more cows? Overview of the beef cowherd and land use. JAM. Proc. Kansas City, MO. P. 121.

Pelletier, N., R. Pirog, and R. Rasmussen. 2010. Comparative life cycle environmental impacts of three beef production strategies in the Upper Midwestern United States. Agric. Syst. 103:380-389. doi:10.1016/j.agsy.2010.03.009.

Population Reference Bureau. 2016. 2016 world population data sheet with a special focus on human needs and sustainable resources. Population Reference Bureau, Washington, DC.

Prior, R. L., and D. B. Laster. 1979. Development of the bovine fetus. J. Anim. Sci. 48:1546-1553.

Quigley, J. D., and J. J. Drewry. 1998. Nutrient and immunity transfer from cow to calf pre-and postcalving. J. Dairy Sci. 81:2779-2790.

Rauw, W. M., E. Kanis, E. N. Noordhuizen-Stassen, and F. J. Grommers. 1998. Undesirable side effects of selection for high production efficiency in farm animals: a review. Livest. Prod. Sci. 56:15-33. doi:10.1016/S0301-6226(98)00147-X.

Reynolds, C. K., B. Dürst, B. Lupoli, D. J. Humphries, and D. E. Beever. 2004. Visceral Tissue Mass and Rumen Volume in Dairy Cows During the Transition from Late Gestation to Early Lactation. J. Dairy Sci. 87:961-971. doi:10.3168/jds.S00220302(04)73240-3. 
Reynolds, C. K., H. F. Tyrrell, and P. J. Reynolds. 1991. Effects of diet forage-toconcentrate ratio and intake on energy metabolism in growing beef heifers: whole body energy and nitrogen balance and visceral heat production. J. Nutr. 121:9941003.

Reynolds, L. P., and D. A. Redmer. 1995. Utero-placental vascular development and placental function. J. Anim. Sci. 73:1839-1851.

Richards, M. W., J. C. Spitzer, and M. B. Warner. 1986. Effect of Varying Levels of Postpartum Nutrition and Body Condition at Calving on Subsequent Reproductive Performance in Beef Cattle. J. Anim. Sci. 62:300-306.

Roche, J. F. 2006. The effect of nutritional management of the dairy cow on reproductive efficiency. Anim. Reprod. Sci. 96:282-296. doi:10.1016/j.anireprosci.2006.08.007.

Sawyer, J. E., C. P. Mathis, and B. Davis. 2004. Effects of feeding strategy and age on live animal performance, carcass characteristics, and economics of short-term feeding programs for culled beef cows. J. Anim. Sci. 82:3646-3653.

Sawyer, J. E. 2015. Strategies to enhance efficiency in intensive systems. In: Dr. Kenneth S. and Caroline McDonald Eng Foundation Symposium. San Antonio, TX. P. 61-72.

Schnepf, R. 2012. US farm income. 
Schroeder, T. C., T. L. Marsh, and J. Mintert. 2000. Beef demand determinants. Rep. Prep. Beef Board Jt. Eval. Advis. Comm.

Selk, G. E., R. P. Wettemann, K. S. Lusby, J. W. Oltjen, S. L. Mobley, R. J. Rasby, and J. C. Garmendia. 1988. Relationships among weight change, body condition and reproductive performance of range beef cows. J. Anim. Sci. 66:3153-3159.

Sibai, B. M., and A. Frangieh. 1995. Maternal adaptation to pregnancy. Curr. Opin. Obstet. Gynecol. 7:420-426.

Siegel, H. S. 1995. Stress, strains and resistance. Br. Poultry. Sci., 36 (1995), pp. 3-22 Siegmund-Schultze, M., B. Rischkowsky, J. B. da Veiga, and J. M. King. 2007. Cattle are cash generating assets for mixed smallholder farms in the Eastern Amazon. Agric. Syst. 94:738-749. doi:10.1016/j.agsy.2007.03.005.

Smith, N. E., and R. L. Baldwin. 1974. Effects of Breed, Pregnancy, and Lactation on Weight of Organs and Tissues in Dairy Cattle. J. Dairy Sci. 57:1055-1060. doi:10.3168/jds.S0022-0302(74)85008-3.

Subervie, J. 2008. The Variable Response of Agricultural Supply to World Price Instability in Developing Countries. J. Agric. Econ. 59:72-92. doi:10.1111/j.14779552.2007.00136.x.

Swingle, R. S., C. B. Roubicek, R. A. Wooten, J. A. Marchello and F. D. Dryden. 1979. Realimentation of cull range cows. 1. Effect of final body condition and dietary energy level on rate, efficiency and composition of gains. J. Anim. Sci. 48:913. 
Tilman, D., K. G. Cassman, P. A. Matson, R. Naylor, and S. Polasky. 2002. Agricultural sustainability and intensive production practices. Nature. 418:671-677. doi:10.1038/nature01014.

Trubenbach, L. A. 2014. Effects of dietary energy density and intake on maintenance requirements in beef cows. Master's thesis. Texas A\&M Univ., College Station.

Tudor, G. D. 1972. Effect of pre-and post-natal nutrition on the growth of beef cattle I. The effect of nutrition and parity of the dam on calf birth weight. Aust. J. Agric. Res. 23:389-395.

Tyrrell, H. F., and P. W. Moe. 1975. Effect of Intake on Digestive Efficiency. J. Dairy Sci. 58:1151-1163. doi:10.3168/jds.S0022-0302(75)84694-7.

USDA. 2013. U.S. drought 2012: farm and food impacts. http://www.ers.usda.gov/topics/in-the-news/us-drought-2012-farm-and-foodimpacts.aspx\#livestock (Accessed 10 May 2016.)

USDA, National Agriculture Statistics Service. 2015. Land values 2015 summary. https://www.usda.gov/nass/PUBS/TODAYRPT/land0815.pdf (Accessed 26 October 2017).

Van Soest, P. J., J. B. Robertson, and B. A. Lewis. 1991. Methods for Dietary Fiber, Neutral Detergent Fiber, and Nonstarch Polysaccharides in Relation to Animal Nutrition. J. Dairy Sci. 74:3583-3597. doi:10.3168/jds.S0022-0302(91)78551-2. 
Vermorel, M., J. C. Bouvier, and Y. Geay. 1976. effect of the genotype (normal and double muscle Charolais and Friesian) on energy utilization by growing cattle at 2 and 16 months of age. Publ Eur Assoc Anim Prod.

Wang, S. L., P. Heisey, D. Schimmelpfennig, and V. E. Ball. 2015. Agricultural Productivity Growth in the United States: Measurement, Trends, and Drivers.

Weaver, D. M., J. W. Tyler, D. C. VanMetre, D. E. Hostetler, and G. M. Barrington. 2000. Passive Transfer of Colostral Immunoglobulins in Calves. J. Vet. Intern. Med. 14:569-577. doi:10.1111/j.1939-1676.2000.tb02278.x.

Wells, S. J., D. A. Dargatz, and S. L. Ott. 1996. Factors associated with mortality to 21 days of life in dairy heifers in the United States. Prev. Vet. Med. 29:9-19.

Whorwood, C. B., K. M. Firth, H. Budge, and M. E. Symonds. 2001. Maternal undernutrition during early to midgestation programs tissue-specific alterations in the expression of the glucocorticoid receptor, 11ß-hydroxysteroid dehydrogenase isoforms, and type 1 angiotensin II receptor in neonatal sheep. Endocrinology. 142:2854-2864.

Wiltbank, J. N., W. W. Rowden, J. E. Ingalls, K. E. Geegoey, and R. M. Koch. 1962. Effect of energy level on reproductive phenomena of mature Hereford cows. J. Anim. Sci. 21:219-225.

Winners, M. D. G. 2009. The Performance of Sustainability-focused Companies in the Financial Crisis. Kearney. 
Worrell, E., J. A. Laitner, M. Ruth, and H. Finman. 2003. Productivity benefits of industrial energy efficiency measures. Energy. 28:1081-1098. doi:10.1016/S0360$5442(03) 00091-4$. 


\section{APPENDIX A}

\section{COW METABOLITE MEASURES}

Table 3.1. Serum metabolite measurements of calves from beef cows fed at four different levels of NRC predicted requirements for maintenance

\begin{tabular}{|c|c|c|c|c|c|c|c|c|}
\hline \multirow[b]{2}{*}{ Item } & \multicolumn{4}{|c|}{ Treatment $^{1}$} & \multirow[b]{2}{*}{ SEM $^{2}$} & \multicolumn{3}{|c|}{ Probability $(\mathrm{P}=)^{9}$} \\
\hline & 70 & 85 & 100 & 115 & & $\mathrm{~L}$ & $\mathrm{Q}$ & $\mathrm{C}$ \\
\hline \multicolumn{9}{|l|}{$\begin{array}{l}\text { At birth, } \\
\mathrm{mg} / \mathrm{dL}\end{array}$} \\
\hline Total Serum & 4.22 & 4.21 & 4.29 & 4.22 & 0.08 & 0.82 & 0.72 & 0.47 \\
\hline \multicolumn{9}{|l|}{ Protein } \\
\hline Albumin & 2.78 & 2.82 & 2.74 & 2.79 & 0.06 & 0.83 & 0.96 & 0.40 \\
\hline Calcium & 12.51 & 11.92 & 12.18 & 11.89 & 0.18 & 0.03 & 0.37 & 0.07 \\
\hline Phosphorus & 7.77 & 7.55 & 7.53 & 7.50 & 0.25 & 0.41 & 0.69 & 0.85 \\
\hline Glucose & 44.83 & 54.33 & 50.43 & 41.21 & 6.29 & 0.57 & 0.12 & 0.77 \\
\hline BUN & 14.68 & 16.60 & 17.69 & 18.41 & 0.85 & $\begin{array}{r}<0.0 \\
1\end{array}$ & 0.46 & 0.90 \\
\hline Creatinine & 3.27 & 3.55 & 3.41 & 3.71 & 0.37 & 0.42 & 0.97 & 0.58 \\
\hline $\mathrm{CK}$ & 141.93 & 195.33 & 208.93 & 151.57 & 49.61 & 0.84 & 0.24 & 0.88 \\
\hline AST & 14.33 & 19.92 & 29.71 & 14.43 & 1.98 & 0.89 & $\begin{array}{r}<0.0 \\
1\end{array}$ & 0.79 \\
\hline GGT & 12.62 & 18.99 & 50.13 & 12.79 & 19.90 & 0.70 & 0.25 & 0.28 \\
\hline Magnesium & 1.93 & 1.98 & 1.96 & 1.99 & 0.07 & 0.61 & 0.89 & 0.68 \\
\hline Sodium & 148.00 & 147.08 & 147.64 & 148.14 & 0.68 & 0.73 & 0.27 & 0.60 \\
\hline Potassium & 4.95 & 4.70 & 4.81 & 4.81 & 0.10 & 0.40 & 0.13 & 0.24 \\
\hline NaK Ratio & 30.10 & 31.36 & 30.85 & 30.90 & 0.67 & 0.45 & 0.30 & 0.38 \\
\hline Cloride & 100.38 & 101.27 & 100.88 & 101.22 & 0.69 & 0.46 & 0.68 & 0.51 \\
\hline \multicolumn{9}{|l|}{$24 \mathrm{~h}$ post birth } \\
\hline Total Serum & 8.15 & 7.73 & 7.53 & 7.49 & 0.42 & 0.15 & 0.57 & 0.96 \\
\hline \multicolumn{9}{|l|}{ Protein } \\
\hline Albumin & 2.20 & 2.28 & 2.24 & 2.28 & 0.57 & 0.39 & 0.64 & 0.41 \\
\hline Calcium & 12.05 & 11.95 & 11.79 & 11.71 & 0.19 & 0.15 & 0.97 & 0.85 \\
\hline Phosphorus & 8.29 & 8.71 & 7.70 & 8.31 & 0.25 & 0.31 & 0.67 & $<0.0$ \\
\hline Glucose & 136.10 & 144.30 & 134.49 & 144.46 & 6.81 & 0.59 & 0.89 & 0.20 \\
\hline BUN & 9.51 & 9.61 & 10.88 & 10.03 & 0.74 & 0.34 & 0.49 & 0.30 \\
\hline Creatinine & 1.43 & 1.45 & 1.43 & 1.34 & 0.09 & 0.38 & 0.52 & 0.93 \\
\hline $\mathrm{CK}$ & 232.43 & 653.58 & 296.00 & 213.71 & $\begin{array}{r}169.5 \\
6\end{array}$ & 0.55 & 0.12 & 0.16 \\
\hline $\mathrm{AST}$ & 60.57 & 72.58 & 68.64 & 65.50 & 5.44 & 0.63 & 0.15 & 0.48 \\
\hline GGT & 2852.2 & 2478.6 & 2369.4 & 2438.0 & 522.8 & 0.51 & 0.64 & 0.97 \\
\hline & 7 & 1 & 9 & 5 & 3 & & & \\
\hline Magnesium & 2.43 & 2.41 & 2.29 & 2.37 & 0.09 & 0.38 & 0.52 & 0.45 \\
\hline & & & 67 & & & & & \\
\hline
\end{tabular}




\begin{tabular}{|c|c|c|c|c|c|c|c|c|}
\hline Sodium & 141.40 & 144.51 & 143.71 & 145.07 & 1.45 & 0.09 & 0.53 & 0.34 \\
\hline Potassium & 5.22 & 5.53 & 5.42 & 5.45 & 0.15 & 0.30 & 0.29 & 0.36 \\
\hline NaK Ratio & 27.39 & 26.23 & 26.86 & 26.79 & 0.77 & 0.68 & 0.42 & 0.42 \\
\hline $\begin{array}{l}\text { Cloride } \\
1 \text { week post } \\
\text { birth }\end{array}$ & 96.84 & 99.77 & 98.94 & 100.66 & 1.20 & 0.05 & 0.52 & 0.25 \\
\hline Total Serum & 7.39 & 7.10 & 6.90 & 6.89 & 0.30 & 0.14 & 0.60 & 0.93 \\
\hline Protein & & & & & & & & \\
\hline Albumin & 2.69 & 2.77 & 2.68 & 2.79 & 0.05 & 0.34 & 0.94 & 0.10 \\
\hline Calcium & 12.95 & 13.07 & 12.15 & 12.04 & 0.23 & $\begin{array}{r}<0.0 \\
1\end{array}$ & 0.60 & 0.06 \\
\hline Phosphorus & 9.63 & 9.01 & 9.26 & 9.72 & 0.46 & 0.74 & 0.15 & 0.70 \\
\hline Glucose & 122.54 & 123.00 & 121.62 & $117.29^{4}$ & 5.08 & 0.41 & 0.61 & 0.96 \\
\hline BUN & 8.62 & 8.75 & 10.48 & $10.01^{4}$ & 0.75 & 0.06 & 0.67 & 0.25 \\
\hline Creatinine & 0.94 & 0.90 & 0.94 & $0.94^{4}$ & 0.04 & 0.71 & 0.53 & 0.54 \\
\hline CK & 83.97 & 101.66 & 118.35 & $142.62^{4}$ & 17.14 & $\begin{array}{r}<0.0 \\
1\end{array}$ & 0.82 & 0.90 \\
\hline AST & 39.40 & 36.65 & 34.28 & $41.67^{4}$ & 2.78 & 0.67 & 0.04 & 0.41 \\
\hline GGT & 567.72 & 539.69 & 402.24 & $437.69^{4}$ & $\begin{array}{r}106.2 \\
1\end{array}$ & 0.21 & 0.74 & 0.53 \\
\hline Magnesium & 1.83 & 1.90 & 1.78 & $1.88^{4}$ & 0.06 & 0.98 & 0.83 & 0.12 \\
\hline Sodium & 141.55 & 141.84 & 141.00 & $142.71^{4}$ & 0.65 & 0.30 & 0.24 & 0.19 \\
\hline Potassium & 5.65 & 5.55 & 5.37 & $5.57^{4}$ & 0.10 & 0.31 & 0.12 & 028 \\
\hline NaK Ratio & 25.17 & 25.64 & $26.34^{5}$ & $25.68^{4}$ & 0.45 & 0.23 & 0.18 & 0.42 \\
\hline Cloride & 94.23 & 93.88 & $95.98^{5}$ & $95.86^{4}$ & 0.75 & 0.02 & 0.86 & 0.13 \\
\hline
\end{tabular}

